\title{
Superparamagnetic Iron Oxide Nanoparticles in Biomedicine: Applications and Developments in Diagnostics and Therapy
}

\author{
Superparamagnetische Eisenoxid-Nanopartikel in der Biomedizin: \\ Anwendungen und Entwicklungen in Diagnostik und Therapie
}

Authors

Affiliation
H. Ittrich, K. Peldschus, N. Raabe, M. Kaul, G. Adam

Diagnostic and Interventional Radiology Department and Clinic, Center für Radiology and Endoscopy, University Medical Center Hamburg-Eppendorf

\author{
Key words \\ - SPIO \\ molecular imaging \\ - MRI \\ - contrast media \\ - iron oxide \\ - nanoparticles
}

eingereicht 25.10 .2012 akzeptiert 18.3.2013

\section{Bibliography}

DOI http://dx.doi.org/

10.1055/s-0033-1335438

Published online: 5.9.2013

Fortschr Röntgenstr 2013; 185:

1149-1166 @ Georg Thieme

Verlag KG Stuttgart · New York .

ISSN 1438-9029

\section{Correspondence \\ Dr. Harald Ittrich}

Diagnostic and Interventional Radiology Department and

Clinic, Center für Radiology and Endoscopy, University Medical Center Hamburg-Eppendorf Martinistraße 52 20246 Hamburg Tel.: ++49/40/428033116 Fax: ++ 49/40/428036799 ittrich@uke.uni-hamburg.de

\section{Abstract \\ $\nabla$}

Superparamagnetic iron oxide nanoparticles (SPIO) can be used to image physiological processes and anatomical, cellular and molecular changes in diseases. The clinical applications range from the imaging of tumors and metastases in the liver, spleen and bone marrow, the imaging of lymph nodes and the CNS, MRA and perfusion imaging to atherosclerotic plaque and thrombosis imaging. New experimental approaches in molecular imaging describe undirected SPIO trapping (passive targeting) in inflammation, tumors and associated macrophages as well as the directed accumulation of SPIO ligands (active targeting) in tumor endothelia and tumor cells, areas of apoptosis, infarction, inflammation and degeneration in cardiovascular and neurological diseases, in atherosclerotic plaques or thrombi. The labeling of stem or immune cells allows the visualization of cell therapies or transplant rejections. The coupling of SPIO to ligands, radio- and/or chemotherapeutics, embedding in carrier systems or activatable smart sensor probes and their externally controlled focusing (physical targeting) enable molecular tumor therapies or the imaging of metabolic and enzymatic processes. Monodisperse SPIO with defined physicochemical and pharmacodynamic properties may improve SPIO-based MRI in the future and as targeted probes in diagnostic magnetic resonance (DMR) using chip-based $\mu N M R$ may significantly expand the spectrum of in vitro analysis methods for biomarker, pathogens and tumor cells. Magnetic particle imaging (MPI) as a new imaging modality offers new applications for SPIO in cardiovascular, oncological, cellular and molecular diagnostics and therapy.
Key Points:

- SPIO can be used for diagnosis, MR imaging, and treatment.

- Monodisperse SPIO improve physicochemistry and pharmacodynamics.

- SPIO in targeted probes can be used in invitro diagnostic imaging ( $\mu \mathrm{NMR}$ ).

- The potential to use SPIO in magnetic particle imaging (MPI) must be evaluated.

Citation Format:

- Ittrich H, Peldschus K, Raabe N et al. Superparamagnetic Iron Oxide Nanoparticles in Biomedicine: Applications and Developments in Diagnostics and Therapy. Fortschr Röntgenstr 2013; 185: 1149-1166

\section{Zusammenfassung \\ $\nabla$}

Mithilfe von Superparamagnetischen EisenoxidNanopartikeln (SPIO) können physiologische Abläufe sowie anatomische, zelluläre und molekulare Veränderungen in Krankheitsprozessen abgebildet werden. Die klinischen Anwendungen reichen von der Tumor- und Metastasenbildgebung in Leber, Milz und Knochenmark, über die Lymphknotenund ZNS-Bildgebung, die MR-Angiografie und Perfusionsdiagnostik bis hin zur atherosklerotischen Plaque- und Thrombosebildgebung. Die experimentellen Anwendungsfelder in der Molekularen Bildgebung umfassen neben ungerichteter SPIOAnreicherung (Passive Targeting) in Entzündungsregionen und Tumoren sowie assoziierten Makrophagen die zielgerichtete Akkumulation von SPIOLiganden (Active Targeting) an/in Tumorendothelien und Tumorzellen, Apoptose-, Infarkt-, Inflammations- und Degenerationsarealen in kardiovaskulären und neurologischen Erkrankungen, in atherosklerotischen Plaques oder Thromben. Die SPIO-Markierung von Stamm- oder Immunzellen erlaubt die Visualisierung von Zelltherapien oder 
Transplantat-Abstoßungen. Die Kopplung von SPIO an Liganden, Radio- und/oder Chemotherapeutika, die Einbettung in Trägersysteme oder aktivierbare Sonden sowie deren extern gesteuerter Fokussierung (Physical Targeting) ermöglicht molekulare Tumortherapien sowie die Abbildung metabolischer und enzymatischer Prozesse. Monodisperse SPIO mit definierten physikochemischen und pharmakodynamischen Eigenschaften könnten die SPIO-unterstützte MRT verbessern und zukünftig als zielgerichtete Sonden in der Diagnostischen Magnetresonanz (DMR) unter Nutzung von chipbasierten $\mu$ NMR das Spektrum der In-vitro-Analysemethoden für Biomarker, Pathogene und Tumorzellen entscheidend erweitern. Magnetic Particle Imaging (MPI) als neues Abbildungsverfahren könnte SPIO sowohl in der kardiovaskulären, onkologischen, zellulären und molekularen Diagnostik und Therapie neue Anwendungsfelder eröffnen.

\section{Introduction}

$\nabla$

The term superparamagnetic, first mentioned in the mid1950 s [1], describes the ability of a ferrimagnetic or ferromagnetic material to be magnetized in the presence of an external magnetic field and to completely lose this magnetization once the magnetic field is deactivated (no remanent magnetization) [2]. This phenomenon is physically based on the Brown and Neel relaxation [3].

Nanoparticles typically refer to particles with a size of $1-100 \mathrm{~nm}$, but the physical, chemical, and biological properties can differ greatly compared to macroscopic material with the same composition [4].

Superparamagnetic particles of iron oxide (SPIO) have an iron oxide core that is monomer- or polymer-coated/stabilized. The advantages of SPIO, such as good suspensibility, a highly reactive surface, uniform particle size distribution, and the possibility of additional coating modification by conjugating with specifically binding ligands (e.g. antibodies) has made it possible to use these particles in biomedicine since the mid-1970s in immunomagnetic cell separation [5].

With the broad application of magnetic resonance imaging (MRI) in medical diagnostics starting in the mid-1980 s, another SPIO application field developed, namely use as a negative, i.e. signal-eliminating, contrast agent in MRI [6]. The nonspecific uptake of SPIO in the mononuclear phagocyte system (MPS) or reticuloendothelial system (RES) after intravenous application made it possible at the end of the $1980 \mathrm{~s}$ to use SPIO in preclinical and clinical diagnostic MRI of organs and organ systems, in particular the liver and spleen [7], and lymph nodes [8] and bone marrow [9]. As a result of systematic further development of SPIO, in particular size variation and coating modifications, numerous additional areas of application in preclinical and clinical MR diagnostics have been tested in the last two decades. Therefore, SPIO have been frequently tested in preclinical feasibility studies as a T1 contrast agent for MR angiography in vascular diagnostics [10], as a T2 or T2* contrast agent for the detection of atherosclerotic plaques [11] and vascular thrombi [12], in perfusion diagnosis of tumors [13], myocardium [14], renal parenchyma [15], vital brain [16], cerebral ischemia [17], and the placenta [18], and in the diagnosis of synovial structures, e.g. in the knee [19]. Newer applications in the primarily still preclinical experimental field of molecular imaging describe on a cellular level the in vitro labeling of cell types (e.g. macrophages, lymphocytes, progenitor/stem cells) with SPIO (cell labeling) and their diagnostic in vivo MR imaging and migration tracking (tracking/migration monitoring) [20, 21]. Additional studies on a molecular level describe the use of SPIO and specifically targeted SPIO conjugates (targeted probes) for labeling cell-surface molecules (e.g. cell receptors or antigens [22]) in combination with gene therapy, chemotherapeutic, or radiotherapeutic agents as a combined diagnostic-therapeutic agent (theranostics [23]) and tumor-thermoablative use in hyperthermia [24]. The embedding of SPIO in nanoencapsulations or microencapsulations with different controllable surface properties (e.g. in micelles or liposomes) recently made it possible to use SPIO in the imaging of metabolic processes (e.g. lipid metabolism [25, 26]). Moreover, the synthesis of novel, monodisperse SPIO with optimized physicochemical and pharmacodynamic properties allows more precise addressing of target structures, greater accumulation in the target area, improved targetenvironment contrast, and more exact parametric or quantitative SPIO-MRI.

In addition to the use of SPIO in diagnostic MRI and in the treatment of diverse diseases, use in a new tomographic imaging modality currently undergoing preclinical evaluation, namely magnetic particle imaging (MPI) [27], is being tested and optimized.

Based on the statements of Taupitz et al. [28], the present study is intended to provide a current overview of the morphological, physical-chemical, and biological characteristics of different SPIO, the current status in clinical application, and the current and future preclinical experimental application fields of SPIO in molecular imaging and treatment.

\section{Particle types and particle properties}

$\nabla$

\section{Definition and magnetic properties in MRI}

Superparamagnetic particles of iron oxide (SPIO) are a separate class of MR contrast agents that have a size spectrum of only a few nanometers to several micrometers and influence the spin-spin (T2) and spin-lattice (T1) relaxation. After local accumulation, SPIO shorten the T2, T2* or T1 relaxation times of surrounding tissues. This causes a signalreducing $\mathrm{T} 2$ and $\mathrm{T} 2 *$ effect (negative contrast) or a signal-increasing $\mathrm{T} 1$ effect (positive contrast). In general, the $r_{2}$ or $r_{2^{*}}$ relaxivity of SPIO as the reciprocal of the T2 or T2* relaxation $\left(r_{2}=1 / \mathrm{T} 2\right.$ or $\left.r_{2^{*}}=1 / \mathrm{T} 2^{*}\right)$ increases with an increasing core diameter, i.e., the signal-reducing effect in T2- and $\mathrm{T} 2$-weighted sequences due to local dephasing in the tissue in the presence of SPIO ("susceptibility effect") is greater at the same local concentration for SPIO with a high $r_{2}$ and $r_{2^{*}}$ than for SPIO with a low $r_{2}$ and $r_{2^{*}}$. In contrast to this behavior, the T1-shortening effect, i.e., the signal-increasing effect in T1-weighted sequences, increases with a smaller SPIO core diameter. Consequently, SPIO with a large diameter are suitable for applications based on the signal reduction of SPIO in T2 and T2*-weighted sequences, while small SPIO are used as signal amplifiers in T1-weighted sequences. This relationship is described by the relaxivity ratio of a SPIO $\left(r_{1} / r_{2}\right)$, i. e., SPIO with a low relaxivity ratio are to be used as a $\mathrm{T} 2 / \mathrm{T}^{*} /$ negative contrast agent and SPIO with a 
high relaxivity ratio as a T1/positive contrast agent. Measured on the basis of the absolute concentration of particles in tissue, SPIO in T2 and T2*-weighted images result in a

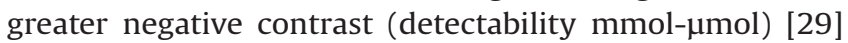
than comparable concentrations of paramagnetic gadolinium (Gd)-containing contrast agent (detectability to cmol-mmol), making SPIO particularly preferred for use in molecular imaging.

With respect to the selection of MR sequences and sequence parameters, it must be stated that gradient echo sequences (GRE, FFE) are more sensitive with respect to magnetic susceptibilities than spin echo sequences (SE) and the sensitivity of the sequence increases with the decrease of the flip angle $\left(\mathrm{FA}<20^{\circ}\right.$ ), extension of the echo time (TE $>10-20 \mathrm{~ms}$ ) and repetition time (TR> $100 \mathrm{~ms})$, and the increase of the spatial resolution (reduction of the partial volume effect) [30]. In addition to these negative-contrast techniques, newer developments in susceptibility-weighted imaging (SWI) use magnitude information as well as phase information from the complex data of spatially highly resolved $3 \mathrm{D}$ gradient echo sequences to generate tissue imaging with improved contrast without using a contrast agent [31-33] or a positivecontrast image after the administration of a contrast agent (e.g. SPIO) [34, 35]. Using suitable post-processing algorithms, susceptibility/phase gradient maps (SGM/PGM) can be created by using voxel-based phase information and creating mask images $[35,36]$. As a result, the contrasts in heterogeneous tissues (e.g., between gray and white brain matter) for the detection of tissue iron deposits or venous blood vessels, as well as the sensitivity to paramagnetic and superparamagnetic substances or contrast agents can be improved. It was able to be shown that these techniques in addition to increasing intrinsic tissue contrasts are also suitable for the detection of the smallest quantities of SPIO (e. g. SPIOlabeled cells), in particular in inhomogeneous tissues or structures with a low signal intensity (e.g. connective tissue) [34].

Particle structure, particle synthesis, and quality control As a rule, SPIO are comprised of a crystalline core and a surrounding core-stabilizing and optionally aggregation-preventing coating whose physical-chemical and associated biological properties can be varied in virtually any way desired ( $\bullet$ Fig. 1). The crystalline core of SPIO is comprised of ferri $\left(\mathrm{Fe}^{3+}\right)$ magnetic and ferro $\left(\mathrm{Fe}^{2+}\right)$ magnetic material in the form of maghemite $\left(\mathrm{\gamma Fe}_{2} \mathrm{O}_{3}\right)$ and magnetite $\left(\mathrm{Fe}_{3} \mathrm{O}_{4}\right)$ and is synthesized in usual protocols with controlled precipitation of iron oxides in aqueous solution (coprecipitation of iron salts by adding a base, e.g. sodium hydroxide, ammonium hydroxide, $<100{ }^{\circ} \mathrm{C}$ ) [37] or in organic solution (high temperature decomposition of iron acetylacetonate in phenyl ether, alcohol, oleic acid or oleylamine [38], $250-300^{\circ} \mathrm{C}$ ). Since it is difficult to control particle size (in particular $<20 \mathrm{~nm}$ ) and to achieve ideal crystallinity and monodispersity (standard deviation of the particle diameter $5-10 \%$ ) in an aqueous solution and the biological properties of monodisperse SPIO and SPIO conjugates with respect to biodistribution, bioelimination, and contrast behavior can be better controlled, which is necessary for targeted use in molecular imaging, high-temperature decomposition synthesis has been increasingly used in recent years [39]. The thus-created cores have a size of a few $(2-3)$ nanometers to multiple tens

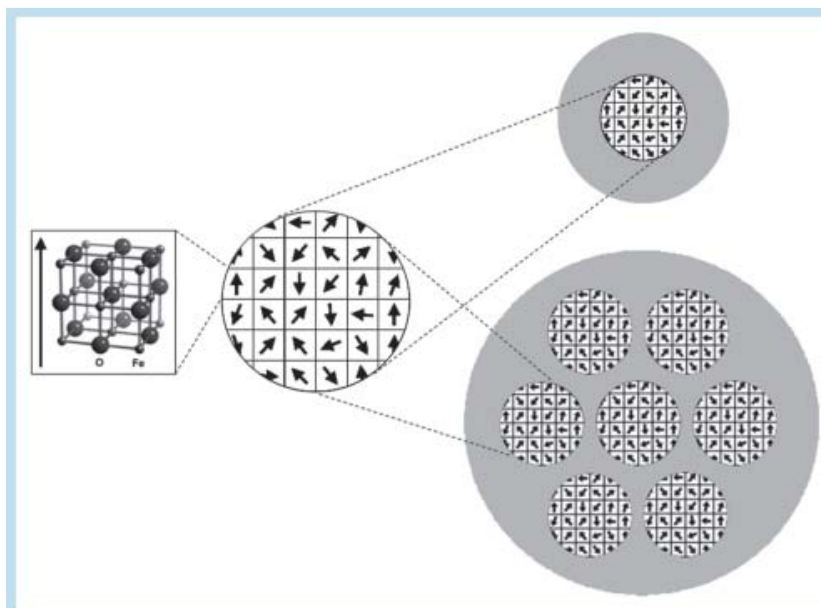

Fig. 1 Schematic structure of a SPIO. In arrangement with randomly aligned (without external magnetic field) additional magnetic domains (middle), the magnetic domain of an iron oxide crystal (left) forms a SPIO crystal/core, which can then be coated with a stabilizing coating material to form a monocrystalline SPIO (upper right) or polycrystalline SPIO (bottom right) (modified according to Wang et al. [34]).

$(20-30)$ of nanometers ( $\bullet$ Fig. 2 ). The synthesizability and stability of SPIO cores decreases with an increasing core diameter so that these can only be reliably created up to a size of approximately $30-40 \mathrm{~nm}$. The coating is then applied by adding a stabilizing base coating material (e.g., citrate, dextran, carboxydextran, chitosan, pullulan, polyethylene glycol (PEG), polyvinyl alcohol (PVA), polyethylenimine (PEI), polyethylene oxide (PEO), polysaccharide, albumin, lipids, etc.) to monocrystalline or polycrystalline SPIO. For in vivo use, organically synthesized SPIO must be transferred to aqueous media by depositing hydrophilic outer coatings. In further steps the particle coating can be secondarily modified, e.g. by the covalent binding of ligands (e.g. proteins, antibodies, etc.). With respect to particle size distribution (dispersity), monodisperse particles, i.e., uniform SPIO with close particle size distribution, can be differentiated from polydisperse, polymorphous SPIO with significant size variance depending on the synthesis.

Size isolation or filtration of the preferred SPIO can be achieved by column chromatography, centrifugation and/or dialysis. Quality control with respect to morphology, core/ coating size, dispersity, and crystallinity can be accomplished using transmission electron microscopy (TEM), X-ray diffraction (XRD), and dynamic light scattering (DLS). The magnetic properties can be determined via nuclear magnetic resonance spectroscopy (NMR) and the iron content via atomic absorption spectroscopy (AAS).

\section{Particle size and coatings}

SPIO are divided into different subgroups according to size [40]. With respect to size, a differentiation must be made between the size of the iron oxide core, the total size of the particle with coating, and the total particle size in aqueous solution after the deposition of water molecules (hydrodynamic diameter). The resulting data regarding particle size in vitro can change when used in vivo due to the additional deposition of salts, opsonization with plasma proteins (e.g. albumin), lipids or carbohydrates (particle corona) depend- 

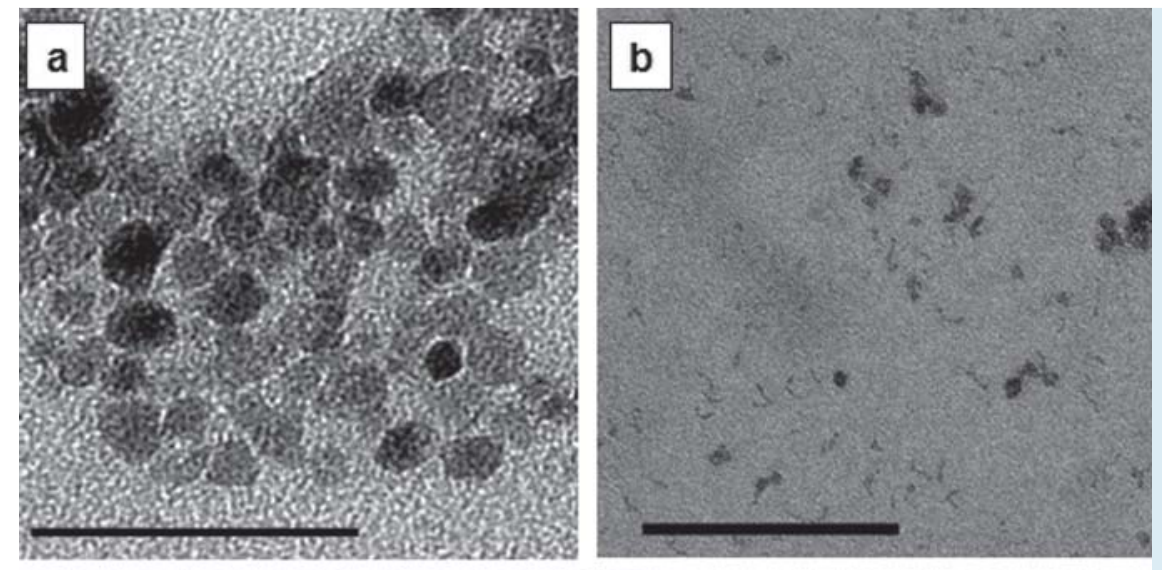

Fig. 2 Superparamagnetic iron oxide particles compared with respect to size and dispersity. Polydisperse SPIO such as a Resovist ${ }^{\circledR}$ (Bayer Healthcare Pharmaceuticals, 50 - $100 \mathrm{~nm}$, upper left, scale $100 \mathrm{~nm}$ ) and $\mathbf{b}$ Sinerem ${ }^{\circledR}$ (Guerbet) upper right, 20 - $40 \mathrm{~nm}$, scale $200 \mathrm{~nm}$ ) manufactured by coprecipitation synthesis in aqueous solution (TEM: $R$. Reimer/H. Hohenberg (HPI Hamburg)), c-f monodisperse USPIO from high temperature decomposition in organic solution, $\mathbf{c}$ SPIO cores $(10 \pm 1 \mathrm{~nm})$ before and $\mathbf{d}$ after PMAcOD coating $(\sim 20 \mathrm{~nm}$, scale $50 \mathrm{~nm}$, TEM: R. Reimer/H. Hohenberg (HPI Hamburg)), e, $\mathbf{f}$ commercially available monodisperse polymers SPIO from Ocean NanoTech (www.oceannanotech.com), e SHP- $15(15 \pm 1.5 \mathrm{~nm}$, scale
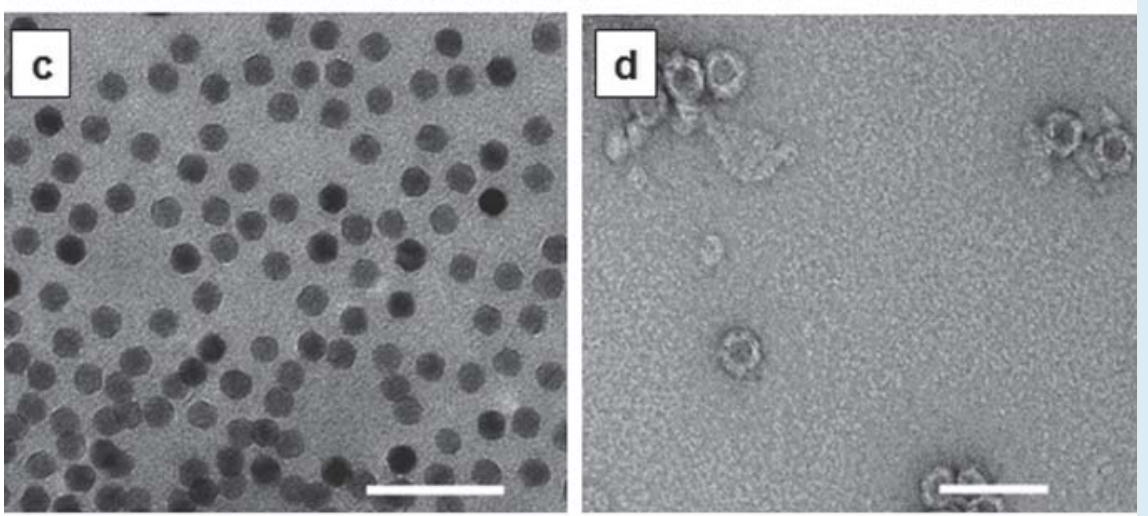
$50 \mathrm{~nm})$ and $\mathrm{f} \mathrm{SHP}-40(40 \pm 4 \mathrm{~nm})$.
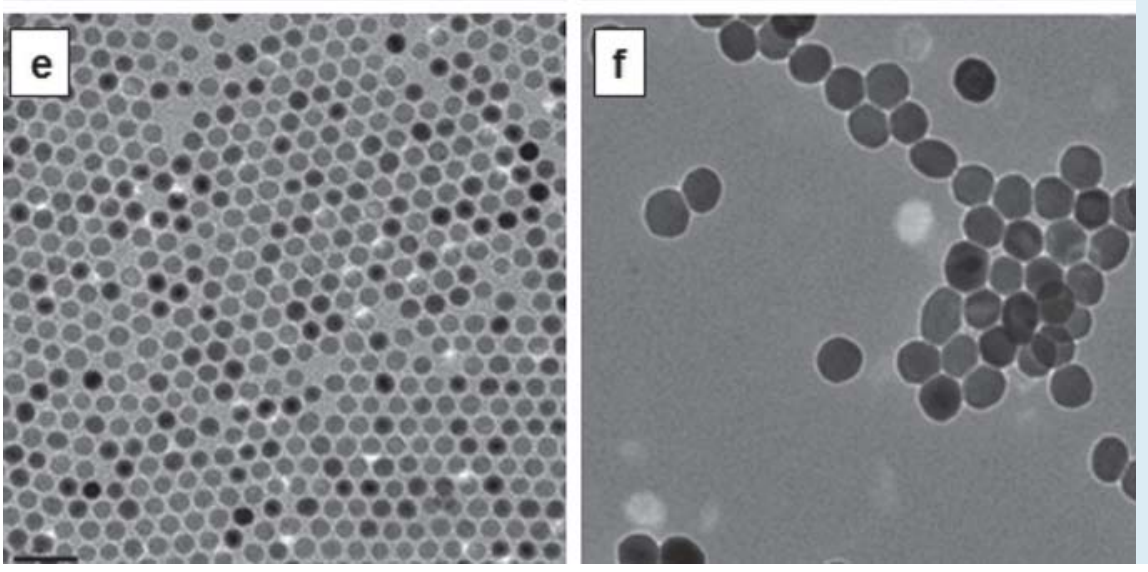

ing on the surface charges of the coating molecules, or due to the clustering of SPIO to form SPIO conglomerates so that the total size in vitro can differ greatly in some cases.

The first iron oxide particles "originally" referred to as SPIO have a size of $40-150 \mathrm{~nm}$ and are referred to as standard SPIO (SSPIO) (e.g. ferumoxide (AMI-25 (Endorem ${ }^{\circledR} /$ Ferri$\left.\operatorname{dex}^{\circledR}\right)$ ), ferucarbotran (SHU 555A (Resovist $\left.{ }^{\circledR}\right)$ ). Comparatively, SPIO of approximately $20-40 \mathrm{~nm}$ are referred to as ultrasmall SPIO (ultrasmall superparamagnetic iron oxide - USPIO) (e.g. ferumoxtran-10 (AMI-227 (Sinerem ${ }^{\circledR} /$ Combidex $\left.^{\circledR}\right)$ ), ferucarbotran (SHU 555C (Supravist $\left.{ }^{\circledR}\right)$ ), (Code 7228 (Rienso $\left.^{\circledR}\right)$ ), PEG-feron $\left(\right.$ NC100 $150\left(\right.$ Clariscan $\left.^{\circledR}\right)$ ) or FeO-BPA. Even smaller SPIO of a size of approximately $15-20 \mathrm{~nm}$ with a polymer coating are classified under consideration of the monocrystalline structure as MION (monocrystalline iron oxide nanoparticles) [41]. The smallest currently synthesizable SPIO have a core of $3-4 \mathrm{~nm}$ and a monomer coating (e. g. citrate) so that total particle sizes of only a few nanometers (ap- proximately $5-7 \mathrm{~nm}$ ) can be realized and are referred to as very small iron oxide particles (VSOP) [42 - 44].

By cross-linking the coating materials, larger SPIO complexes that can reach a size of several micrometers and be classified as CLIO (cross-linked iron oxide) can also be created [45]. Moreover, the formation of larger SPIO particle constructs by embedding SPIO in different coating systems (e.g. micelles or liposomes) is currently being tested [25]. As a result, on the one hand clustering of the SPIO in a small space with an increase in the $\mathrm{R} 2$ / $\mathrm{R} 2$ * relaxation rate is achieved and on the other hand the surface properties of natural biological transport systems are used or imitated in order to image their distribution processes noninvasively. This includes the embedding of SPIO in lipoprotein-lipid coatings (nanosomes $[25,26])$ or the embedding of oleic acid-stabilized SPIO and optionally additional therapeutic agents in cross-linked phospholipid nanoemulsions referred to as colloidal iron oxide nanoparticles (CION). With the latter construct, a plat- 


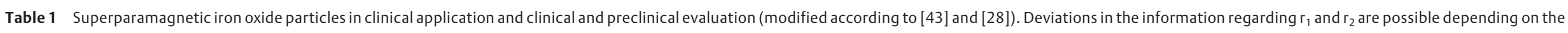
source

\begin{tabular}{|c|c|c|c|c|c|c|c|c|c|c|c|c|c|c|c|}
\hline $\begin{array}{l}\text { name/ } \\
\text { reference }\end{array}$ & $\begin{array}{l}\text { generic } \\
\text { name }\end{array}$ & $\begin{array}{l}\text { registered } \\
\text { name }\end{array}$ & core & $\begin{array}{l}\text { con- } \\
\text { trast }\end{array}$ & type & $\begin{array}{l}\text { core size/ } \\
\text { hydrodyn. } \\
\text { diameter [nm] }\end{array}$ & coating & $\begin{array}{l}\mathrm{r}_{1} \\
{\left[\mathrm{mMol}^{-1}\right.} \\
\left.\mathrm{Is}^{-1}\right]^{*}\end{array}$ & $\begin{array}{l}\mathrm{r}_{2} \\
{\left[\mathrm{mMol}^{-1}\right.} \\
\left.\mathrm{Is}^{-1}\right]^{*}\end{array}$ & $\frac{r_{1}}{r_{2}}$ & $\begin{array}{l}\text { blood } \\
\text { half-life } \\
\left(T_{1 / 2}\right)\end{array}$ & $\begin{array}{l}\text { concentra- } \\
\text { tion }\end{array}$ & indication & $\begin{array}{l}\text { application/ } \\
\text { development - } \\
\text { phase }\end{array}$ & $\begin{array}{l}\text { manufacturer/dis- } \\
\text { tributor }\end{array}$ \\
\hline $\begin{array}{l}\text { AMI-25 [34, } \\
195-200]\end{array}$ & Ferumoxide & $\begin{array}{l}\text { Feridex }^{\circledast} \text {, } \\
\text { Endorem }^{\circledR}\end{array}$ & $\mathrm{Fe}^{3+} / \mathrm{Fe}^{2+}$ & $\mathrm{T} 2$ & SPIO & $\begin{array}{l}5-6 \\
80-150\end{array}$ & Dextran & $\begin{array}{l}30^{1} \\
+9.9^{2}\end{array}$ & $\begin{array}{l}100^{1} \\
158^{2}\end{array}$ & $\begin{array}{l}0.3^{1} \\
0.07^{2}\end{array}$ & $8 \mathrm{~min}$. & $\begin{array}{l}11.2 \mathrm{mg} \mathrm{Fe} / \\
\mathrm{ml}\end{array}$ & $\begin{array}{l}\text { liver, spleen, } \\
\text { bone marrow }\end{array}$ & approved $^{3}$ & $\begin{array}{l}\text { AMAG Pharmaceu- } \\
\text { ticalsGuerbet }\end{array}$ \\
\hline $\begin{array}{l}\text { SHU 555A } \\
{[196,198,} \\
199,201- \\
203]\end{array}$ & $\begin{array}{l}\text { Ferucarbo- } \\
\text { tran }\end{array}$ & $\begin{array}{l}\text { Resovist }^{\circledR}, \\
\text { Cliavist }^{\circledR}\end{array}$ & $\mathrm{Fe}^{3+} / \mathrm{Fe}^{2+}$ & $\mathrm{T} 2$ & SPIO & $\begin{array}{l}4.2 \\
50-100\end{array}$ & $\begin{array}{l}\text { Carboxy- } \\
\text { dextran }\end{array}$ & $\begin{array}{l}25.4^{1} \\
9.7^{2}\end{array}$ & $\begin{array}{l}151^{1} \\
189^{2}\end{array}$ & $\begin{array}{l}0.17^{1} 0.0- \\
5^{2}\end{array}$ & $10 \mathrm{~min}$. & $0.5 \mathrm{mmol} / \mathrm{l}$ & $\begin{array}{l}\text { Liver, spleen, } \\
\text { bone marrow }\end{array}$ & $\begin{array}{l}\text { approved }{ }^{4} \mathrm{EU}, \\
\text { Japan, Australia, } \\
\text { (ØUSA) }\end{array}$ & $\begin{array}{l}\text { Bayer Healthcare } \\
\text { Pharmaceuticals }\end{array}$ \\
\hline $\begin{array}{l}\text { AMI-227 } \\
{[34,95,196,} \\
197,202, \\
204]\end{array}$ & $\begin{array}{l}\text { Ferumox- } \\
\text { tran-10 }\end{array}$ & $\begin{array}{l}\text { Sinerem }{ }^{\circledR}, \\
\text { Combidex }{ }^{\circledR}\end{array}$ & $\mathrm{Fe}^{3+} / \mathrm{Fe}^{2+}$ & $\begin{array}{l}\mathrm{T} 2, \\
(\mathrm{~T} 1)\end{array}$ & USPIO & $\begin{array}{l}4-6 \\
20-40\end{array}$ & Dextran & $\begin{array}{l}31^{1} \\
19.5^{2}\end{array}$ & $\begin{array}{l}78^{1} \\
87.6^{2}\end{array}$ & $\begin{array}{l}0.39^{1} \\
0.22^{2}\end{array}$ & $\begin{array}{l}24- \\
30 \mathrm{~h}\end{array}$ & $20 \mathrm{mg} \mathrm{Fe} / \mathrm{ml}$ & $\begin{array}{l}\text { MRA, liver, } \\
\text { spleen, bone } \\
\text { marrow }\end{array}$ & phase $1 I^{5}$ & $\begin{array}{l}\text { GuerbetAMAG } \\
\text { Pharmaceuticals }\end{array}$ \\
\hline $\begin{array}{l}\text { P904 [74, } \\
168]\end{array}$ & - & - & $\mathrm{Fe}^{3+} / \mathrm{Fe}^{2+}$ & $\mathrm{T} 1, \mathrm{~T} 2$ & USPIO & $\begin{array}{l}4-6 \\
21\end{array}$ & $\begin{array}{l}\text { Amino-alco- } \\
\text { hol- glucose- } \\
\text { derivative }\end{array}$ & $14^{2}$ & $87^{2}$ & $0.16^{2}$ & $3.5 \mathrm{~h}$ & & $\begin{array}{l}\text { MRA, athero- } \\
\text { sclerosis, } \\
\text { adiposity }\end{array}$ & preclinical & Guerbet \\
\hline $\begin{array}{l}\text { SHU 555C } \\
{[81,203]}\end{array}$ & $\begin{array}{l}\text { Ferucarbo- } \\
\text { tran }\end{array}$ & Supravist $®$ & $\mathrm{Fe}^{3+} / \mathrm{Fe}^{2+}$ & $\begin{array}{l}\mathrm{T} 2 \\
(\mathrm{~T} 1)\end{array}$ & USPIO & $\begin{array}{l}3-4 \\
20-30\end{array}$ & $\begin{array}{l}\text { Carboxy- } \\
\text { dextran }\end{array}$ & $\begin{array}{l}18^{1} \\
11^{2}\end{array}$ & $\begin{array}{l}41^{1} \\
38^{2}\end{array}$ & $\begin{array}{l}0.44^{1} \\
0.29^{2}\end{array}$ & $6-8 h$ & $0.5 \mathrm{mmol} / \mathrm{l}$ & $\begin{array}{l}\text { MRA, lymph } \\
\text { nodes }\end{array}$ & phase $I^{6}$ & $\begin{array}{l}\text { Bayer Healthcare } \\
\text { Pharmaceuticals }\end{array}$ \\
\hline $\begin{array}{l}\text { Code } 7228 \\
{[159,197,} \\
202]\end{array}$ & Ferumoxytol & $\begin{array}{l}\text { Feraheme }{ }^{\circledR} \\
\text { Rienso }{ }^{\circledR}\end{array}$ & $\mathrm{Fe}^{3+} / \mathrm{Fe}^{2+}$ & $\mathrm{T} 1$ & USPIO & $\begin{array}{l}6-7 \\
28-32\end{array}$ & $\begin{array}{l}\text { Carboxyme- } \\
\text { thyl-dextran }\end{array}$ & $38^{2}$ & $83^{2}$ & $0.46^{2}$ & $\begin{array}{l}10- \\
14 \mathrm{~h}\end{array}$ & $\begin{array}{l}30 \mathrm{mg} \mathrm{Fe} / \\
\mathrm{mL}\end{array}$ & MRA & $\begin{array}{l}\text { approved for } \\
\text { iron } \\
\text { deficiency ane- } \\
\text { mia }\end{array}$ & $\begin{array}{l}\text { AMAG Pharmaceu- } \\
\text { ticals, Takeda Phar- } \\
\text { maceutical Com- } \\
\text { pany Limited }\end{array}$ \\
\hline $\begin{array}{l}\text { NC100 } \\
150[34, \\
196]\end{array}$ & $\begin{array}{l}\text { Feruglose- } \\
\text { PEG-feron }\end{array}$ & Clariscan $®$ & $\mathrm{Fe}^{3+} / \mathrm{Fe}^{2+}$ & $\mathrm{T} 2, \mathrm{~T} 1$ & USPIO & $\begin{array}{l}4-7 \\
11-20\end{array}$ & Starch/PEG & $20^{1}$ & $35^{1}$ & $0.57^{1}$ & $6 \mathrm{~h}$ & $\begin{array}{l}29.8 \mathrm{mg} \mathrm{Fe} / \\
\mathrm{mL}\end{array}$ & $\begin{array}{l}\text { MRA, lymph } \\
\text { nodes, liver, } \\
\text { spleen }\end{array}$ & phase III & GE Healthcare \\
\hline $\begin{array}{l}\text { FeO-BPA } \\
{[91]}\end{array}$ & - & - & $\mathrm{Fe}^{3+} / \mathrm{Fe}^{2+}$ & $\mathrm{T} 1$ & USPIO & $\begin{array}{l}5-7 \\
20\end{array}$ & $\begin{array}{l}\text { Oxidized } \\
\text { starch }\end{array}$ & $20^{2}$ & $35^{2}$ & $0.57^{2}$ & $\begin{array}{l}45- \\
100 \mathrm{~min} .\end{array}$ & - & MRA & preclinical & \\
\hline $\begin{array}{l}\text { MION-46L } \\
{[205-208]}\end{array}$ & - & - & $\mathrm{Fe}^{3+} / \mathrm{Fe}^{2+}$ & $\begin{array}{l}\mathrm{T} 2, \\
(\mathrm{~T} 1)\end{array}$ & MION & $\begin{array}{l}4-6 \\
8-20\end{array}$ & Dextran & $16.5^{1}$ & $34.8^{1}$ & $0.47^{1}$ & $>10 \mathrm{~h}$ & - & $\begin{array}{l}\text { MRA, lymph } \\
\text { nodes, tumor, } \\
\text { infarction }\end{array}$ & preclinical & \\
\hline $\begin{array}{l}\text { VSOP-C184 } \\
{[36,37,196,} \\
207-210]\end{array}$ & - & - & $\mathrm{Fe}$ & $\mathrm{T} 1$ & VSOP & $\begin{array}{l}4-5 \\
7-9\end{array}$ & Citrate & $\begin{array}{l}19^{1} \\
14^{2}\end{array}$ & $\begin{array}{l}29^{1} \\
33.4^{2}\end{array}$ & $\begin{array}{l}0.66^{1} \\
0.42^{2}\end{array}$ & $\begin{array}{l}30- \\
60 \mathrm{~min} .\end{array}$ & $0,5 \mathrm{mmol} / \mathrm{l}$ & MRA & phase I & Ferropharm GmbH \\
\hline $\begin{array}{l}\text { AMI-121 } \\
{[211]}\end{array}$ & Ferumoxil & $\begin{array}{l}\text { Gastro- } \\
\text { MARK } ®, \text { Lumi- } \\
\text { rem } \circledast\end{array}$ & $\mathrm{Fe}^{3+} / \mathrm{Fe}^{2+}$ & $\mathrm{T} 2$ & SPIO & $10>300$ & Silicon & $3.4^{7}$ & $3.8^{7}$ & $0.89^{7}$ & $<5 \mathrm{~min}$. & $\begin{array}{l}52.5 \mathrm{mg} \mathrm{Fe} / \\
300 \mathrm{~mL}\end{array}$ & gastrointestinal & approved & $\begin{array}{l}\text { AMAG Pharmaceu- } \\
\text { ticals Guerbet }\end{array}$ \\
\hline $\begin{array}{l}\text { OMP } \\
{[34]}\end{array}$ & Ferristene & Abdoscan ${ }^{\circledR}$ & $\mathrm{Fe}^{2+}$ & $\mathrm{T} 2$ & SPIO & $\begin{array}{l}50 \\
3000-3500\end{array}$ & $\begin{array}{l}\text { Styrol/ } \\
\text { divinylbenzene }\end{array}$ & no data & no data & no data & & $\begin{array}{l}23.4 \mathrm{Fe} / \\
200 \mathrm{ml}\end{array}$ & gastrointestinal & $\begin{array}{l}\text { approved in EU } \\
\text { to } 2002 \text {, (ØFDA) }\end{array}$ & GE Healthcare \\
\hline
\end{tabular}

${ }^{1}$ Measured at $0.47 \mathrm{~T}, 37^{\circ} \mathrm{C}$.

${ }^{2}$ Measured at $1.5 \mathrm{~T}, 37^{\circ} \mathrm{C}$

${ }^{3}$ No longer produced and distributed since 2011.

${ }^{4}$ No longer distributed in Europe since 2009, only available in Japan (international pharmacy).

${ }^{5}$ Application for clinical approval from EMEA withdrawn in 2007.

${ }^{6}$ No longer being developed.

${ }^{7}$ Measured at $0.97 \mathrm{~T}, 37^{\circ} \mathrm{C}$ 
Table 2 Selection of some of the manufacturers of experimental SPIO

\begin{tabular}{|c|c|c|}
\hline manufacturer & location/head office & website \\
\hline $\begin{array}{l}\text { Bangs Laboratories, } \\
\text { Inc. }\end{array}$ & $\begin{array}{l}9025 \text { Technology Drive } \\
\text { Fishers, IN } 46038-2886 \\
\text { USA }\end{array}$ & www.bangslabs.com \\
\hline $\begin{array}{l}\text { Centrum für Ange- } \\
\text { wandte Nanotechno- } \\
\text { logie (CAN) GmbH }\end{array}$ & $\begin{array}{l}\text { Grindelallee } 117 \\
20146 \text { Hamburg } \\
\text { Germany }\end{array}$ & www.can-hamburg.de \\
\hline Chemicell GmbH & $\begin{array}{l}\text { Eresburgstraße } 22-23 \\
12103 \text { Berlin } \\
\text { Germany }\end{array}$ & www.chemicell.com \\
\hline Ferropharm GmbH & $\begin{array}{l}\text { Potsdamer Str. 18a } \\
14513 \text { Teltow } \\
\text { Germany }\end{array}$ & www.ferropharm.de \\
\hline $\begin{array}{l}\text { Kisker Biotech GmbH } \\
\& \text { Co. KG }\end{array}$ & $\begin{array}{l}\text { Postbox } 1329 \\
48543 \text { Steinfurt } \\
\text { Germany }\end{array}$ & $\begin{array}{l}\text { www.kisker-biotech. } \\
\text { com }\end{array}$ \\
\hline MagForce AG & $\begin{array}{l}\text { Max-Dohrn-Str. 8, Haus B } \\
5.2 \\
10589 \text { Berlin } \\
\text { Germany }\end{array}$ & www.magforce.de \\
\hline $\begin{array}{l}\text { Micromod Partikel- } \\
\text { technologie GmbH }\end{array}$ & $\begin{array}{l}\text { Friedrich-Barnewitz-Str.4 } \\
18119 \text { Rostock } \\
\text { Germany }\end{array}$ & www.micromod.de \\
\hline Miltenyi Biotec GmbH & $\begin{array}{l}\text { Friedrich-Ebert-Straße } 68 \\
51429 \text { Bergisch Gladbach } \\
\text { Germany }\end{array}$ & $\begin{array}{l}\text { www.miltenyibiotec. } \\
\text { com }\end{array}$ \\
\hline NanoPET Pharma & $\begin{array}{l}\text { Robert-Koch-Platz } 4 \\
10115 \text { Berlin } \\
\text { Germany }\end{array}$ & $\begin{array}{l}\text { www.nanopet-pharma. } \\
\text { com }\end{array}$ \\
\hline Ocean Nanotech & $\begin{array}{l}2143 \text { Worth Lane Spring- } \\
\text { dale, Arkansas } 72764 \\
\text { USA }\end{array}$ & $\begin{array}{l}\text { www.oceannanotech. } \\
\text { com }\end{array}$ \\
\hline Phosphorex, Inc. & $\begin{array}{l}94 \text { South Street } \\
\text { Hopkinton, Ma } 01748 \\
\text { USA }\end{array}$ & www.phosphorex.com \\
\hline Spherotech, Inc. & $\begin{array}{l}27845 \text { Irma Lee Circle, } \\
\text { Unit } 101 \\
\text { Lake Forest, IL } 60045 \\
\text { USA }\end{array}$ & www.spherotech.com \\
\hline
\end{tabular}

form for simultaneous imaging and treatment (theranostics) is proposed [46]. An overview of the SPIO currently used in clinical application and testing is provided in 0 Table 1. SPIO of different size, shape, dispersity, coating, and functionalization can currently be commercially procured from different manufacturers for experimental, preclinical testing. 0 Table 2 provides an overview of several manufacturers.

\section{Distribution, degradation and toxicity}

The size and surface properties (in particular charge) have a decisive influence on the elimination, cell response, and toxicity of SPIO [47]. Thus, SPIO with a small hydrodynamic diameter and neutral and hydrophilic surface are opsonized and phagocytized more slowly than large SPIO with an ionic and hydrophobic coating. SSPIO are phagocytized or endocytized by monocytes, macrophages, or oligodendroglial cells of the RES and are thus removed from the blood stream so that they have a comparably short blood half-life of a few minutes [48] (AMI-25: 8 min., SHU-555A: $10 \mathrm{~min}$.) [49]. SSPIO accumulate primarily in the liver $(80-90 \%)$, spleen $(5-8 \%)$, and bone marrow $(1-2 \%)$ [49]. In comparison, USPIO and VSOP have a longer blood half-life which makes it possible to use these as blood pool contrast agents (e.g. blood half-life AMI-227: 200 min., SHU 555C: 6-8h, VSOP-C184: $30-60$ min.) [49]. Small particles of less than $5 \mathrm{~nm}$ can pass through the glomerulus and be eliminated renally [50].

After uptake of the SPIO in autochthonous, specialized macrophages of the liver (Kupffer cells), these are degraded lysosomally [51], and the core material is supplied to the iron storage pool of the body (total body iron approximately 4 $5 \mathrm{~g}$ ) and deposited in the liver in the form of ferritin and/or hemosiderin [52]. The natural decomposition of these iron reserves is only possible via hematopoiesis $\left(\mathrm{Fe}^{2+}\right.$ as central atom in the hemoglobin) and the exfoliation of epithelial cells of the skin and bowel. The coating material is eliminated via other decomposition and elimination paths, e.g. the coating of ferumoxtran-10 (Sinerem ${ }^{\circledR}$ ) is degraded via intracellular dextranases and is eliminated primarily renally (89\% in 8 weeks) [53].

It has been able to be shown experimentally in vitro that polymer-coated SPIO (PEG/dextran-SPIO) only have a minimal effect on cell function and vitality [54]. However, newer studies show that internalized SPIO can influence the cell expression pattern (e.g. by oxidative stress), cell proliferation, and cell differentiation [55]. Methods for core labeling (e.g. ${ }^{59} \mathrm{Fe}[56]$ ) and coating labeling with radioisotopes [57] (e. g. ${ }^{111} \mathrm{In}[58],{ }^{64} \mathrm{Cu}$ [59], ${ }^{99 \mathrm{~m}} \mathrm{Tc}[60]$ or ${ }^{14} \mathrm{C}$ ) and quantitative evaluation methods have been proposed to clarify the SPIO metabolic processes, i. e., in vivo biodistribution and biodegradation of the core and coating material, prior to a potential clinical application, particularly to clarify any possible nanoparticle toxicity.

In diagnostic concentrations ( 20 - $50 \mathrm{mg} \mathrm{Fe}$ ), no toxic side effects after i.v. injection of SPIO have been observed to date [61]. Headache or back pain, vasodilation, hypotension, or allergic reaction in the form of urticaria can occur on rare occasions [62]. No systemic toxic effects have been observed in animal experiments at concentrations up to $100 \mathrm{mg} \mathrm{Fe} / \mathrm{kg}$ [63]. The amount of a chronic iron overload (>20 g) is not reached even when used multiple times.

\section{SPIO in clinical application}

$\checkmark$

The SPIO currently in clinical application are used in MR imaging to take advantage of their $\mathrm{T} 2 / \mathrm{T} 2 * / \mathrm{T} 1$-shortening effect. Blood elimination occurs nonspecifically via natural phagocytic elimination mechanisms, so-called "passive targeting". The accumulation of SPIO in tissue is used for T2/ T2* imaging, the T1 effect during blood circulation. The blood half-life and the phagocytic elimination by the RES are largely influenced by the particle size (hydrodynamic diameter) and the surface properties (chemical composition/charge) of the SPIO.

\section{T2/T2* applications}

Liver imaging

SPIO with a hydrodynamic diameter of $100-150 \mathrm{~nm}$ (SSPIO) are nonspecifically absorbed by Kupfer cells (autochthonous macrophages) of the normal liver parenchyma resulting in a loss of signal of the liver tissue in T2w and T2*s MRI. Primary liver malignancies (hepatocellular carcinoma (HCC), cholangiocellular carcinoma (CCC)) or secondary liver malignancies (metastases) do not have any Kupffer cells so that there is no 


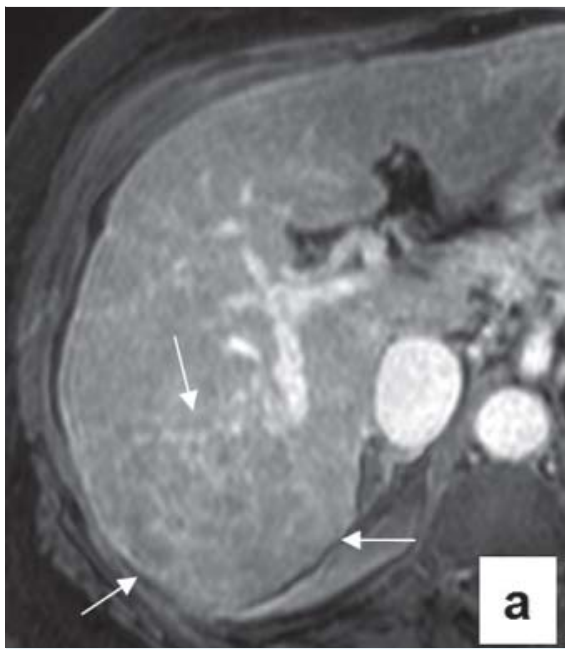

Fig. 3 Liver with multifocal HCC a T1w MRI 5 min. after i.v. application of Gd-DTPA and $\mathbf{b}$ T2* $w$ MRI before and $\mathbf{c}$ after i. v. administration of SPIO (ferucarbotran (Resovist $\left.{ }^{\circledR}\right)$ ). Accumulation of SPIO in Kupffer cells of the
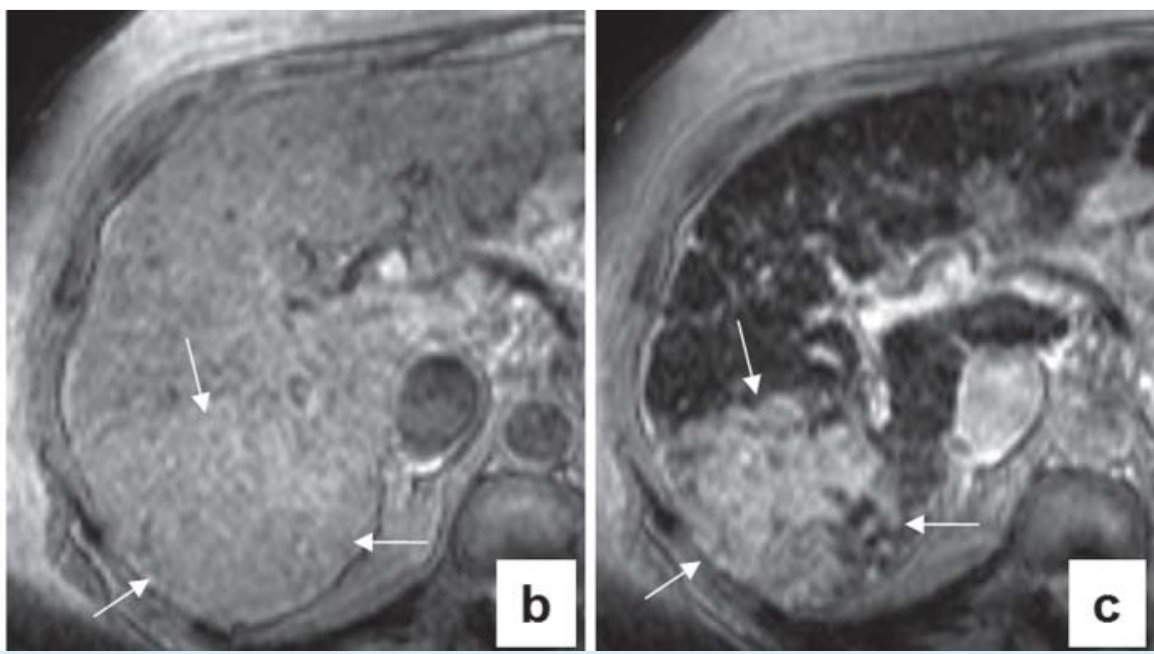

liver results in a significant signal loss in the normal, healthy liver parenchyma with a lack of signal reduction in the HCC lesions (white arrows).
SSPIO accumulation in these lesions and no T2w/T2* $\mathrm{w}$ signal loss [64] ( $\bullet$ Fig. 3). Consequently, the lesion-to-liver contrast increases. This increases the sensitivity for detecting tumorous lesions [65] and can also improve the classification of liver tumors and the grading [66] and delimitation of an HCC with respect to benign liver tumors or hyperplastic nodes [67]. The two SSPIO available in clinical use were ferumoxide (Endorem ${ }^{\circledR}$, Guerbet) [68] and ferucarbotran (Resovist ${ }^{\circledR}$, Bayer Healthcare Pharmaceuticals) [69]. However, the production and sale thereof have been discontinued since 2011 for Endorem ${ }^{\circledR}$ and 2009 for Resovist ${ }^{\circledR}$ in Europe due to the small sales market and the introduction of the hepatobiliary Gdbased contrast agent, Gd-EOB (Primovist ${ }^{\circledR}$, Bayer Healthcare Pharmaceuticals), with an improved ability to detect liver lesions [70]. Resovist ${ }^{\circledR}$ is only still sold on the Japanese market and can be procured there (international pharmacy).

To avoid nephropathy or the risk of nephrogenic systemic fibrosis (NSF) when using a Gd-containing contrast agent in patients with limited kidney function (glomerular filtration rate (GFR) $<30 \mathrm{ml} / \mathrm{min}$. per $1.73 \mathrm{~m}^{2}$ ), SPIO can be a safe alternative for detecting and differentiating liver lesions [71].

\section{Spleen imaging}

Analogously to the liver, the accumulation of SPIO in spleen macrophages improves the detection of metastases or rare primary spleen tumors by increasing the lesion-to-spleen contrast [65]. Another application field is the diagnosis of heterotopic splenic tissues, such as an accessory spleen or splenosis. In this case, SPIO can aid differentiation with respect to pancreatic tumors (intrapancreatic accessory spleen) or peritoneal metastases (splenosis after splenectomy or abdominal trauma) due to the accumulation in these lesions [72].

\section{Lymph node imaging}

Smaller SPIO (USPIO, hydrodynamic diameter $\sim 30 \mathrm{~nm}$ ) can be used for MR lymphography and for lymph node staging following intravenous or local subcutaneous injection. Due to the longer circulation time of dextran-coated USPIO as a result of the lower accumulation in the RES of the liver and spleen and the small size of USPIO compared to SSPIO, these can exit the vascular system after intravenous application (extravasation), are transported lymphogenically, and are absorbed physiologically in the lymph nodes by macrophages, resulting in a signal loss of the lymph nodes in T2W and in particular T2* $\mathrm{w}$ gradient echo sequences. Depending on the extent of the lymph node invasion, metastatic lymph nodes exhibit this signal loss only partially or not at all as could be shown in clinical studies in carcinomas of the head-neck [73], breast [74], bronchus [75], esophagus [76], stomach [77], rectum [78], and in pelvic/urological carcinomas [79], and can therefore result in an improvement of the lymph node staging. However, USPIO are currently not approved for clinical application. Due to the not definitively proven improvement of the specificity of MR for the detection of metastatic lymph nodes using Sinerem ${ }^{\circledR}$ in a main study in phase III (MR lymph node analysis in pelvic carcinoma patients), the application for clinical approval of Sinerem ${ }^{\circledR}$ from the EMEA was retracted by Guerbet in 2007 (doc. ref. EMEA/595 122/2007). A further USPIO development with a similar application spectrum called P904 is currently undergoing preclinical evaluation [80].

\section{Tumor imaging}

SPIO can cause signal reductions in $\mathrm{T} 2 \mathrm{~W}$ and $\mathrm{T} 2 * \mathrm{~W}$ pulse sequences in tumor regions due to the direct uptake in tumor cells and tumor-associated macrophages or via the increased extravasation in tumor-associated vessels with increased capillary leakiness. This was able to be observed clinically in liver metastases [81] and was shown experimentally in gliosarcomas and gliomas [82, 83].

\section{Bone marrow imaging}

As in the macrophages in the liver and spleen, the increased uptake in phagocytic cells of bone marrow results in a signal loss in T2w or T2* $\mathrm{w}$ pulse sequences [9]. The lack of focal or diffuse signal loss signalizes an infiltration by malignant cells also in this case [84]. In addition, differences in the signal behavior of inflammatory medullary cavity lesions (os- 
teomyelitis) and irradiated, hematopoietic, or reconverted bone marrow compared to normal or metastatic bone marrow after SPIO application are described [85].

\section{Imaging of the gastrointestinal tract}

Non-degradable and non-absorbable ferrofluids with large diameters $(0.3-3.5 \mu \mathrm{m})$ can be applied after oral administration for suppression of the water signal of the bowel (Lumirem ${ }^{\circledR} /$ GastroMARK $^{\circledR}$ (Guerbet/AMAG Pharmaceuticals), Abdoscan $^{\circledR}$ (GE Healthcare). This can be used to prevent overlapping in magnetic resonance cholangiopancreatography (MRCP), for better delimitation with respect to structures adjacent to the bowel (e.g. lymph nodes or uterus) and the evaluation (postoperative) of anatomical changes to the bowel [86], as well as for the detection of inflammatory bowel lesions after i.v. administration [87].

\section{CNS imaging}

The suitability of SPIO for MRI of the CNS was able to be shown in neurovascular (infarction [88]), neuro-oncological (tumors [89]) or neuroinflammatory processes (multiple sclerosis (MS) [90]) as well as for angiography and perfusion diagnosis [91]. Increased accumulation of SPIO in the microglia of the CNS in the case of disruption of the blood brain barrier (BBB) in tumorous CNS lesions [89] or inflammatory CNS lesions [92] which can be imaged with the help of $\mathrm{T} 2 \mathrm{w} / \mathrm{T} 2 * \mathrm{w}$ MR sequences is observed in the case of the former applications.

\section{Characterization of atherosclerotic plaques}

Soft plaques, which are currently known to have a predisposition for acute atherothrombotic vascular occlusion and are vulnerable due to the high lipid content and the thin fibrous cap, have an increased macrophage content and efficient SPIO labeling is the goal of T2w and T2* $\mathrm{w}$ MR imaging of atherosclerotic lesions ( $\bullet$ Fig. 4). As a result, the increased accumulation of USPIO in atherosclerotic plaques could be proven both preclinically $[11,80,93]$ and clinically [94], in particular in carotid plaques [95], in numerous studies but has not yet been widely used clinically.

\section{T1 applications}

Magnetic resonance angiography (MRA)

The relaxivity ratio $\left(r_{1} / r_{2}\right)$, which increases as the particle diameter decreases, the sufficiently high $r_{1}$ relaxivity, and the comparatively long intravasal circulation times of USPIO and VSOP (blood pool contrast agent) allow application as a T1 contrast agent in luminographic MR vascular diagnostics (magnetic resonance angiography (MRA)). Numerous preclinical and several clinical studies describe their use both in MRA of individual vascular territories, such as pulmonary arteries [96], the aorta [80,97], coronary arteries [10, 98, 99], renal arteries [10], mesenterial and portal veins [100], hepatic veins [101], and the inferior vena cava [102], as well as in whole-body angiography of arteries and veins for assessing stenoses and thromboses [103]. Potential USPIO for clinical application are Supravist ${ }^{\circledR}$ (SHU 555C, phase I, Bayer Healthcare Pharmaceuticals), AMI-227 (Sinerem ${ }^{\circledR}$, phase III), and VSOP-184 (phase I). However, the dominance of the Gd-based contrast agent, which is quickly eliminated renally and has a safe application profile, has prevented the broad use of USPIO in MRA. In addition to contrast-free an-
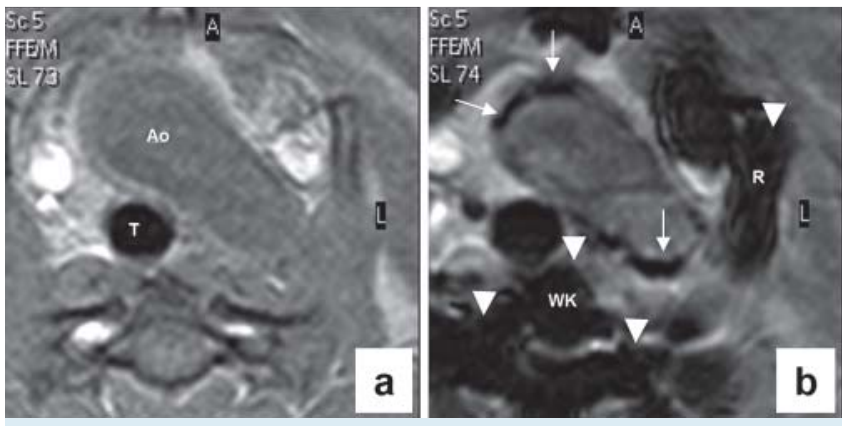

Fig. 4 Atherosclerotic plaques a before and $\mathbf{b}$ after SPIO. After i. v. application of SPIO, there is signal loss of inflammatory atherosclerotic plaques (arrows) due to the accumulation of SPIO in plaque-associated macrophages (transverse slice orientation through the aortic arch, experimental in hereditary hyperlipidemic Watanabe (WHHL) rabbits, T-trachea). Osseous structures such as vertebral bodies/arches and ribs also show an increased signal loss (arrow tips) due to accumulation of SPIO in macrophages of the bone marrow.

giography techniques [104], contrast-enhanced MRA using USPIO and VSOP could be used as a safe alternative to Gdcontaining contrast agents in patients with limited renal function (low GFR) to prevent contrast-induced nephropathy or the risk of NSF [71].

\section{Thrombosis diagnosis}

Luminographic T1w MR techniques using long-circulating blood pool SPIO (USPIO and VSOP) make it possible to diagnose thromboses in venous vessels that can be visualized indirectly as contrast-free areas in venous MRA [103] or experimentally with direct thrombus visualization [12].

\section{Perfusion diagnosis}

The T1 and T2 / T2* effect of USPIO and VSOP can be used in dynamic contrast-enhanced MRI (DCE-MRI) and dynamic susceptibility-weighted MRI (DSC-MRI) and the T1 and T2 / T2* effect of long-circulating USPIO can also be used in steady state free precision MRI (SSFP-MRI) for perfusion diagnosis of organs or organ lesions. The microvascular permeability [105] can be determined via T1w DCE-MRI during the wash-in phase, and the fractional plasma volume in tissues/tumors, which is closely correlated with the vessel density and the vessel size index, can be determined via SSFP-MRI via the change in the R2 / $R 2 *$ relaxation rates before and after USPIO application ( $\triangle \mathrm{R} 2$ or $\left.\Delta \mathrm{R} 2^{*}\right)$ [106]. These noninvasively determined parameters can show the effectiveness of antiangiogenic or antitumoral treatments prior to a change in tumor size [107]. Organ and lesion perfusion diagnosis via USPIO and VSOP could be shown using the example of the heart [99], liver [108], spleen [65], and kidneys [109].

\section{SPIO in preclinical and experimental application} $\nabla$

Molecular imaging

Due to their variable size, the excellent signal properties in T2w and T2 $w^{*}$ MRI, the possible coating variations and the consequently diverse conjugation options or functionalizations (targeting molecules), the simple biodegradation (iron 
metabolism), the ability to label with fluorescent dyes, radioisotopes, and therapeutic agents, and the simple traceability in correlative analysis procedures (light/electron microscopy), small SPIO (USPIO and MION) are suitable for use in molecular imaging for synthesizing targeted molecular probes (active targeting). Therefore, the spectrum of applications for SPIO and their derivatives has expanded continuously in recent years. Initial proof-of-concept experiments have helped different application areas for SPIO to become established in the last decade and some have found their way into clinical studies (e.g. SPIO cell labeling).

\section{SPIO conjugation with antibodies and antibody fragments \\ $\nabla$}

The conjugation of SPIO with specific ligands, such as antibodies, peptides, polysaccharides, nucleotides, aptamers, and other synthetic mimetics, for generating targeted vectorized contrast agents (targeted SPIO) theoretically offers virtually unlimited applications in MR imaging of tumors, inflammation, cardiovascular, neurovascular, or degenerative diseases with close parallels to the developments in nuclear medicine (radioactively labeled ligands) [110].

Particularly in regard to antibodies (AB), SPIO can be conjugated with complete antibodies (SPIO-AB), monovalent antibody fragments, diabodies, triabodies, tetrabodies, singlechain antibodies, or minibodies [111]. If most successful studies were performed at high field strengths of up to $7 \mathrm{~T}$, their translation to $1.5 \mathrm{~T}$ is also described [112]. Limitations on the use of SPIO-AB are currently the limited sensitivity of MRI, in particular in the case of low-expression target structures (low antigen density/receptor density, usually $1-100 \mathrm{nmol}$ ) and the small SPIO size (usually USPIO) needed for a long circulation time, extravasation capability, and tissue penetration. Currently successful concepts for increasing the specific accumulation of SPIO-AB are based on the receptor-mediated uptake of SPIO-AB conjugates in the target cells (intracellular trapping) [113] or on a 2-step strategy in which a target-recognizing biotinylated antibody and then a streptavidin-conjugated SPIO are injected [114]. The extremely high biotin-(strept)avidin binding affinity ensures accumulation of the conjugated SPIO in the target tissue.

\section{Tumor imaging}

In tumor imaging, antibody-SPIO conjugates were able to be used to successfully image numerous surface markers overexpressed in tumor vessels and cells, such transferrin receptor [115], folic acid receptor [116], VEGF [117], RGD [118], $\alpha_{v} \beta_{3}$-integrin as angiogenesis marker [119], Her2/neu (cerb B-2) tyrosinase receptor [114], uMUC-1 [120], LHRH-R [121], EGFR [122], CEA [123], CEACAM5 (○ Fig.5) [124], CXCR4 [125], CD20 [126] or B220 + (B-cell lymphomas) [127] with the help of T2w or T2*W MRI. An alternative, older approach is SPIO labeling of non-tumorous target structures for "inverse" imaging of tumors as was successfully shown in liver cells in an animal model (asialoglycoprotein (AGP) receptor) for the detection of liver neoplasias [128] or in pancreas cells (cholecystokinin $\mathrm{A}(\mathrm{CCKA})$ receptor) for the identification of pancreas tumors [129].

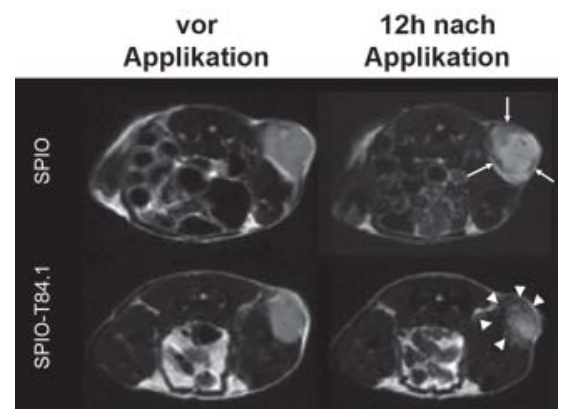

Fig. 5 Molecular tumor imaging with SPIO-conjugated antibodies. T2* $\mathrm{W}$ MRI of C57BI/6-SCID mice with FEMX-I tumors (CEACAM expression) of the left flank before (left) and after (right) i. v. administration of SPIO (upper row) shows minimal signal loss in the tumor periphery $12 \mathrm{~h}$ after application (arrows), caused by non-specific SPIO accumulation in tumor-associated macrophages. After the application of targeted T84.1-SPIO conjugates (bottom row), there is significant signal loss primarily in the highly vascularized tumor periphery due to specific AB-SPIO tumor binding (arrow tips), from Pöselt et al. [117].

\section{Apoptosis imaging}

Cell apoptosis plays an important role in numerous neoplastic, neurodegenerative, inflammatory, and cardiovascular-ischemic diseases. Successful MR imaging of apoptotic cells in vivo was able to be performed using targeted SPIO against phosphatidylserine after the conjugation of SPIO with the C2 domain of synaptotagmin I [130], annexin V [131], or annexin A5 [132].

\section{Cardiovascular imaging}

Expanding the spectrum of MR imaging using non-targeted USPIO already performed in clinical studies, specific, targeted USPIO were used in an attempt to address target structures in cardiovascular diseases, such as atherosclerosis, thrombosis, and myocardial infarction, to increase the $\mathrm{T} 2 \mathrm{w} / \mathrm{T} 2 \mathrm{w}^{*}$ signal-reducing effects via specific accumulation of the targeted SPIO and to thus detect earlier stages of the diseases.

As a result, apoptotic foam cells [133], oxidation-specific epitopes (malondialdehyde-lysine-epitopes of MDA-LDL [134]), oxidized phospholipid epitopes [134], scavenger receptors type A (with sulfated, dextran-coated SPIO) [135], VCAM-1 [136], E- and P-selectin [136], or oxidated LDL [137] in vulnerable and inflammatory plaques were able to be successfully labeled.

In molecular myocardial infarction imaging, the use of MION-conjugated antimyosin- $\mathrm{F}_{\mathrm{ab}}$ (MION-R11D10) against myosin for labeling an infarcted myocardium is described [138].

In thrombus diagnosis, target structures in thrombuses, such as $\alpha_{2} \beta_{3}$-intergrin [139], of activated thrombocytes [140] or activated coagulation factor XIII (FXIIIa) [141] were able to be successfully addressed.

\section{Cell labeling and cell imaging in MRI}

The ex vivo loading or labeling of cells with SPIO (cell labeling) allows the in vivo imaging and tracking (migration monitoring) of SPIO-labeled cells in T2w and T2w* MRI after application ( $\bullet$ Fig. 6 ).

Efficient ex vivo labeling of cells can be achieved by coating modifications, e.g. by coating with liposomes [142], by 


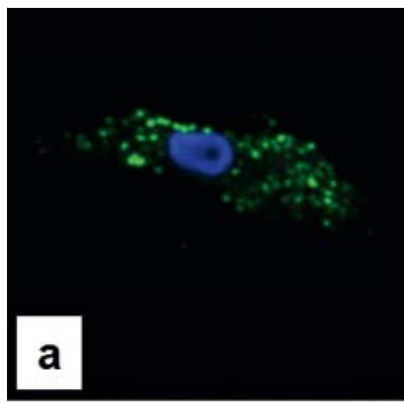

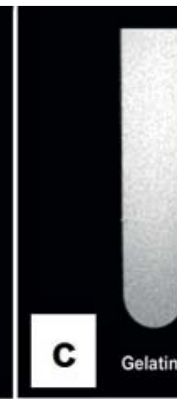
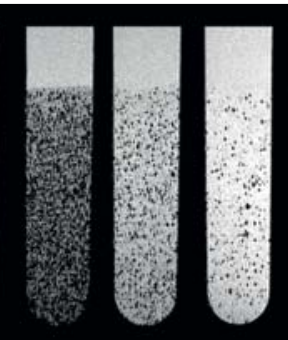

15000

5000

1500

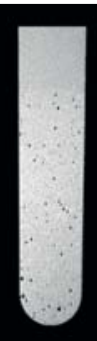

500
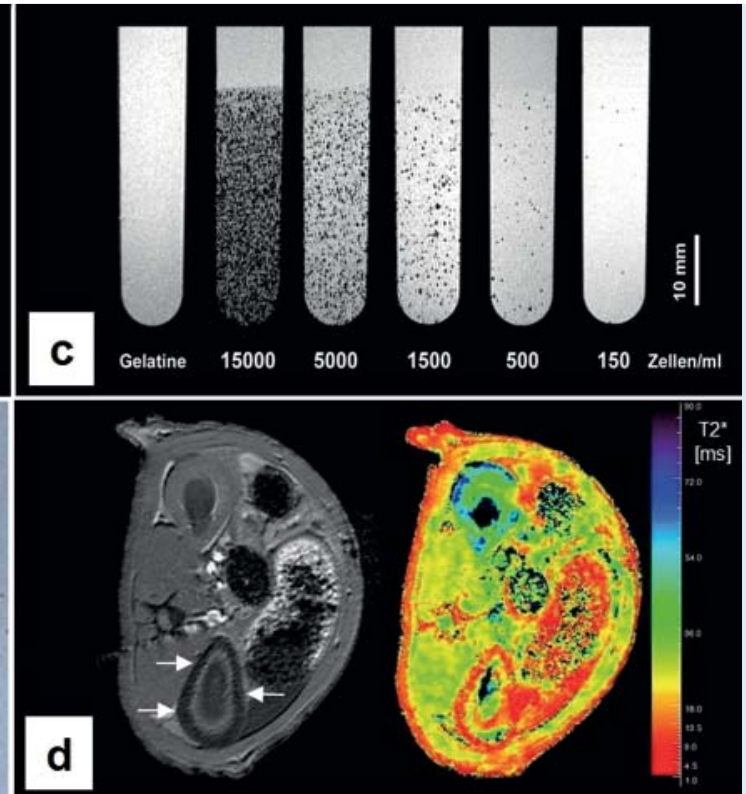

Fig. 6 Cellular imaging of SPIO-labeled mesenchymal stem cells (MSC). a Fluorescence microscopy and $\mathbf{b}$ native light microscopy of a singular MSC after labeling with coating-fluorescence-labeled SPIO (cell core after DAPI staining, blue). c In vitro T2 ${ }^{*} \mathrm{w}$ MRI of different quantities of SPIO-labeled MSC embedded in gelatin. $\mathbf{d}$ In vivo T2* ${ }^{*}$ MRI and corresponding relaxometric $\mathrm{T}^{*}$ map (in $\mathrm{ms}$ ) of SPIO-labeled MSC in the renal cortex of the left kidney (glomeruli) after selective application in the left renal artery.
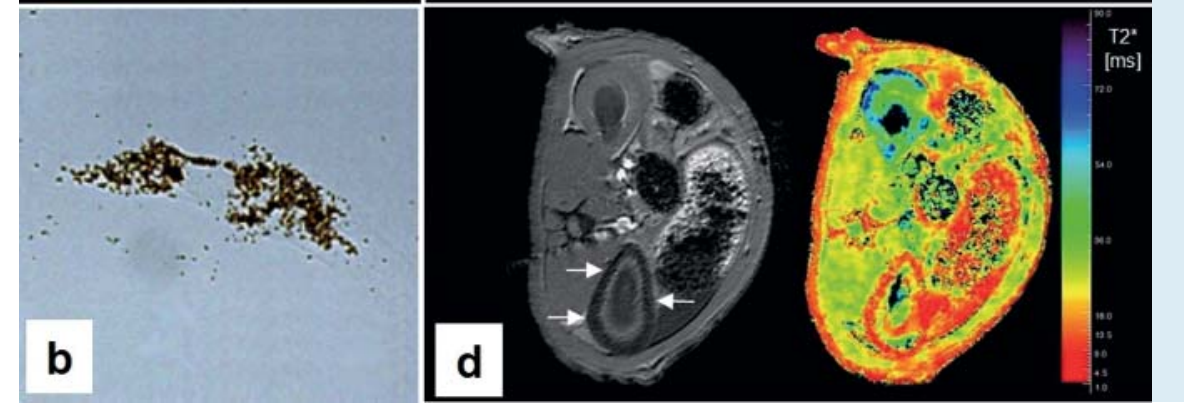

using lectins [143], by conjugating antigen-specific monoclonal antibodies (MION-46 L [144]), or by binding specific peptide chains (HIV-1 Tat peptide) to the dextran coating of SPIO (MION-Tat, CLIO-Tat [145]). Moreover, the use of transfection media [146], polyamines, lipids, or dendrimers [147] can result in enhanced cellular SPIO incorporation. Due to the partially complicated labeling protocols, simplified strategies using clinically approved materials (e.g. Endorem $^{\circledR} /$ Feridex $^{\circledR}$, Superfect ${ }^{\circledR}$, Lipofectamine Plus ${ }^{\circledR}$, poly-Llysine (PLL), protamine) and low cell toxicity have been described in recent years [148, 149]. While most studies do not describe any significant changes in cell behavior (e.g. apoptosis rate, proliferation index, differentiation behavior) [150, 151], individual studies show changes in migration behavior and the ability to form colonies [152], in cell vitality [153], in differentiation behavior [154], or in the expression pattern [152]. By the same token, the influence of cell labeling on the long-term behavior of cells and the course of disease is currently unclear [155] and must be studied more closely in the future [156].

Successful in vivo detection and migration monitoring of SPIO-labeled cells was able to be demonstrated in numerous studies, e. g. in implanted hematopoietic, mesenchymal, or neuronal stem cells in the CNS [157], heart [158], liver [159], spleen [160], bone marrow [160], kidneys [161], joints [162], and muscles [163], endothelial progenitor cells [164], transplanted islet cells [165], and lymphocytic and moncytic cells (natural killer cells in oncological cell therapies [166]). Moreover, the migration of macrophages in apoptotic tissue replacement [167], tumors [168], or vascular aneurysms [169] was able to be visualized in vivo. With respect to in vivo sensitivity, it is possible under ideal conditions to detect single SPIO-labeled cells [170].

\section{Transplant diagnostics, imaging of rejection reactions (graft rejection)}

The increased local presence of macrophages and the associated increased accumulation of SPIO during a rejection and changes in the permeability of transplant vessels were able to be imaged in MRI in an animal model during the rejection of heart [171] and kidney transplants [172].

\section{Inflammation, infection, and adiposity imaging}

As in the imaging of rejection reactions, SPIO also accumulate in the macrophages of inflammatory lesions. Therefore, it was able to be shown in animal experiments that non-infections synovial inflammation in arthritis models can be imaged using intravenously injected USPIO [173].

In a similar manner, the macrophage presence [174] and the increased extravasation of USPIO [175] in the edge region of bacterial soft tissue abscesses were able to be shown in T2w and T2* w MRI after i. v. USPIO application.

Moreover, macrophages were able to be detected experimentally as markers of low-grade chronically inflamed activity of fat tissue in adipose mice after the i. v. injection of USPIO [176].

\section{Imaging of multiple sclerosis (MS) and neurodegeneration}

When using SPIO to image the CNS, neuroinflammation (MS) and neurodegeneration (e.g. Alzheimer plaques) are in the foreground. In small animal models of MS (experimental autoimmune encephalomyelitis (EAE)), SPIO can be used to image macrophage activity [177] and infiltration [178], lymphocyte infiltration $\left(\mathrm{CD}^{+}\right.$cells [179]) and the labeling of T-cells [180]. Also in the case of heart attack, numerous studies show that SPIO can image the accompanying neuroinflammation or the macrophage activity [181] and macrophage migration [182] similarly to the changes in MS. Moreover, it was able to be shown that early stages of post-radiogenic brain damage can be imaged via targeted SPIO-AB against ICAM-1 [183].

With respect to the use of SPIO in the imaging of neurodegenerative diseases such as Alzheimer's disease, amyloid beta plaques were able to be successfully addressed via MION-AB [184] or SPIO-AB against amyloid-beta 42 [185]. 


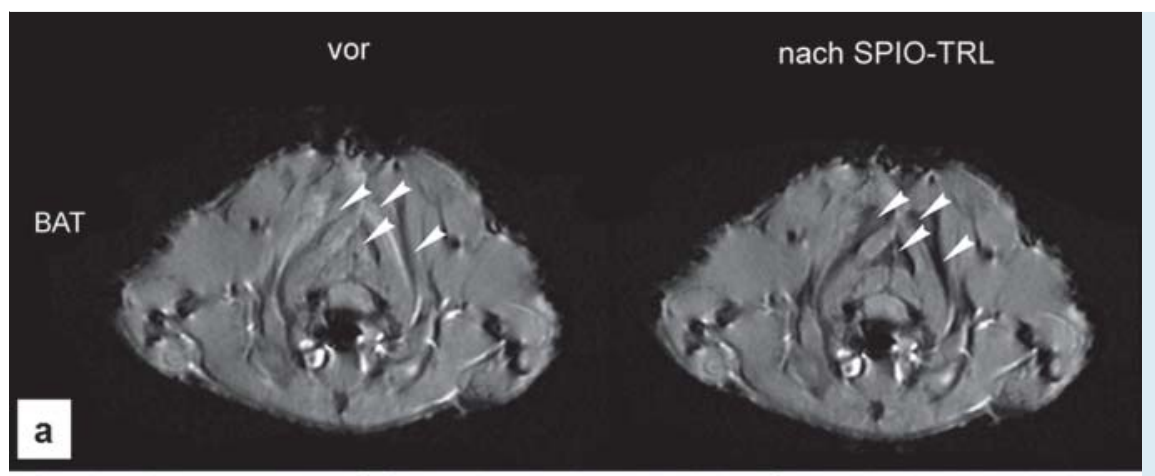

Fig. 7 Metabolic imaging. a Interscapular brown adipose tissue (BAT) of mice exposed to cold before (upper left) and after (upper right) i. v. application of SPIO-labeled triglyceride-rich lipoproteins (SPIOTRL) with significant signal loss of the BAT due to cellular uptake of the SPIO-TRL (white arrow tips). b-d TEM images prove the internalization of SPIOTRL in brown adipocytes and aggregation in endosomes (scale bar: b $1 \mu \mathrm{m}, \mathbf{c} 0.05 \mu \mathrm{m}$, d $20 \mathrm{~nm}$; from Bartelt et al. [26]).

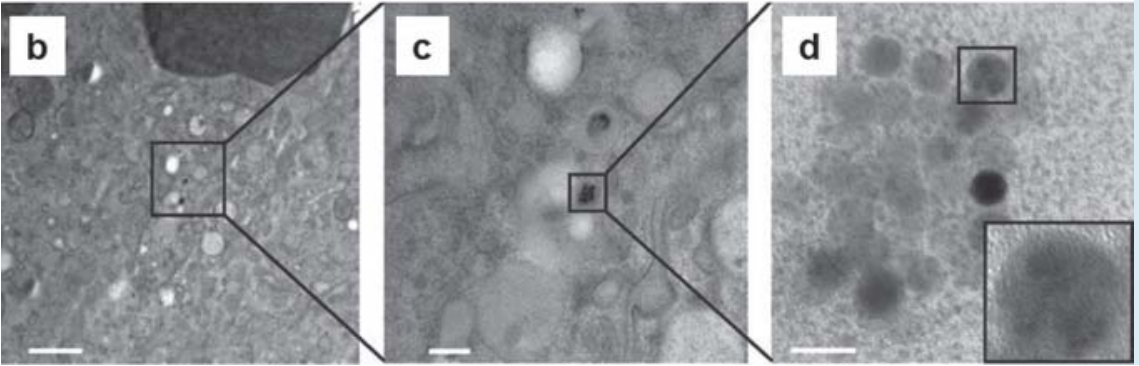

\section{Metabolic imaging}

Newer studies show the promising use of SPIO in lipid-metabolism MR imaging by embedding in lipoprotein carriers, such as nanosomes [25]. In these studies the enzyme activity of the lipoprotein lipase in brown adipose tissue in rodents was able to be visualized via SPIO nanosomes [26]. Like ${ }^{18} \mathrm{FDG}$-PET, this type of imaging using SPIO nanosomes therefore has the potential to image metabolic conditions, i. e. enzymatic activity in tissues, in real time (Fig. 07 ).

\section{Imaging of enzymatic activity}

In addition to the use of nanosomes, other studies describe the successful visualization of enzymatic activity in tissues in MRI using so-called activatable "smart sensor probes" [186 - 188]. These probes are initially inactive but generate a significant contrast in the presence of the target enzyme due to a change or switch in their magnetic relaxivity (magnetic relaxivity switch (MRS)) as a result of a transition from a disperse state to an aggregated state [188-190]. The principle of MRS could be shown both for specially prepared T1 contrast agents (e.g. $\beta$-galactosidase activity [191]) and for VSOP or CLIO (e. g. metalloproteinase-9 activity [192], telomerase activity $[193,194])$ and can be used for in vitro MRS assays as well as potentially in vivo. For example, MMP-9activatable protease-specific VSOP (MMP9-PSOP) lose their stabilizing coating of PEG copolymers in the presence of the target enzyme (protease) due to the enzyme-specific splitting of a coating-binding protein. As a result of the consequently accessible positive (coupling proteins) and negative charges (citrate coating) of the VSOP coating, particle aggregation, R2 relaxivity increase, and focal reduction of the T2w and T2 $\mathrm{w}^{*}$ MR signal occur and can be used as a measure of the enzyme/protease activity. The VSOP-based protease-sensitive nanosensors (PSOP) introduced by Schellenberger et al. have a number of properties favoring potential in vivo use as a "reporter probe" in MRI since these can be synthesized comparatively easily and can in principle be used for different proteases, and the particle size of PSOP $(\sim 25 \mathrm{~nm})$ in association with the $\mathrm{MPEG}$ coating guarantees long bioavailability [192]. In principle, the MRS method should also be able to be transferred to other proteolytic enzymes (nucleases, polysaccharidases, proteases), which can be used in in vitro assays and potentially also in in vivo MR diagnostics [190].

\section{Comparison of SPIO and Gd-containing contrast agents (Gd-CA) in MRI}

Although problems with the use of SPIO have been reported in individual cases (e.g. allergic reactions), these are generally to be viewed as a safe contrast agent [63, 195-201]. Due to the relatively low molecular size of Gd-CA (about $1 \mathrm{~nm}$ ), the simple application properties, the good tissue penetration and extravasation (dynamic contrast agent properties), the fast renal elimination and resulting ability to use them multiple times in short intervals, and the less artifact-prone imaging, Gd-CA are the contrast agent of choice in many areas of application and SPIO remain a supplementary contrast agent. Exceptions include patients with limited kidney function or renal insufficiency in whom SPIO can be a safe alternative to prevent contrast-induced nephropathy or nephrogenic systemic fibrosis [71]. A disadvantage of currently used, often polydisperse, SPIO and SPIO conjugates is the frequently short blood circulation time and thus the short target structure contact time due to the fast uptake in the liver, spleen, bone marrow, which often results in an only minimal accumulation in the target structure and tracer dispersion in non-targeted tissue. The advantage of the higher sensitivity of MRI for SPIO (mmol- $\mu \mathrm{mol})$ can typically only conditionally compensate for this disadvantage. Nonetheless, cellular or molecular MR imaging and therapy are currently a domain of SPIO [29]. Newer synthesis methods producing monodisperse SPIO with better defined physicochemical and pharmacodynamic properties could greatly increase the importance of SPIO-enhanced MRI in the future [202] and the frequency of SPIO use in contrast-enhanced MRI. 


\section{Molecular therapy}

In principle, the treatment of tumors using targeted SPIO can follow three different approaches: 1) Targeted SPIO bind specifically to the tumor receptor which selectively suppresses tumor growth, 2) targeted SPIO are used for magnetically induced hyperthermia after tumor binding, and 3) targeted SPIO are loaded with therapeutic agents (drug targeting) and these accumulate in the target tissue [23].

The effective binding and tumor growth inhibition of SPIOanti-Her2-AB against breast cancer cells (SKBr3) [203], of anti-EGFRvIII-SPIO against glioblastoma cells [204], or of cetuximab-anti-EGFR immunomicelles against A431 malignant cells [205] was shown in the first approach.

The second strategy was able to be successfully shown by binding magnetoliposome-antibody complexes to MN antigens of renal cell carcinoma cells [206], magnetoliposomeanti-Her2-AB to breast cancer cells [203], or anti-folate receptor-SPIO to different tumor cell lines [207].

The third strategy was able to be successfully proven on the basis of rhenium188-loaded immuno(hepama-1)magnetic nanoparticles (Re-SPIO-AB) against liver carcinoma cells [208], methotrexate-conjugated SPIO against breast (MCF7) and cervical (HeLa) carcinoma cells [209], doxorubicin-loaded nanomicelles [210], doxorubicin-carrying hyaluronanSPIO (DOX-HA-SPIO) [211], docetaxel-carboxymethylcellulose-SPIO [212], layer-by-layer (LbL) polyelectrolyte capsules that can be loaded with SPIO and/or therapeutic agents [213], SPIO- and doxorubicin-loaded cetuximab-anti-EGFR immunomicelles or with doxorubicin(liposomal)-loaded macrophages (macrophage-LP-Dox) that accumulate in tumors [214].

Although major advances in tumor labeling and tumor therapy via therapeutic imaging SPIO constructs (theranostics) have been made in recent years, the development of potent in vivo theranostics with high specificity and sensitivity has remained a significant challenge due to the heterogeneity of the expression level of the target structure on the tumor cells and problems with overcoming physiological barriers (e.g. extravasation or blood-tissue barriers) preventing access to the target cell (pharmacological accessibility).

\section{Magnetic beads, MACS, and magnetofection}

In addition to their use in imaging, particularly MRI, and in molecular therapy (hyperthermia, therapeutic agent transporter, or gene transporter), SPIO are also used in other biomedical applications. With the use of SPIO in in vitro diagnostics since the $1970 \mathrm{~s}$ [5], the spectrum has also continually expanded in this regard. Using magnetic beads in cytobiological research, this includes the in vitro filtration and sorting of proteins and peptides, nucleic acids, and cells (e. g. tumor or stem cells) $[215,216]$ and in vitro magnetofection of cells with DNA [217].

Iron oxide particles with a size of approximately 50 nanometers to several micrometers (microbeads) are referred to as magnetic beads. They have good magnetic properties and often a coating of silicon oxide or polystyrene and different coupling groups, such as streptavidin, carboxyl groups, protein $A$ or $G[218,219]$. In addition to iron oxide particles $\left(\mathrm{YFe}_{2} \mathrm{O}_{3} / \mathrm{Fe}_{3} \mathrm{O}_{4}\right)$, cobalt, manganese, and nickel ferrite particles $\left(\mathrm{CoFe}_{2} \mathrm{O}_{4}, \mathrm{MnFe}_{2} \mathrm{O}_{4}, \mathrm{NiFe}_{2} \mathrm{O}_{4}\right)$ are also used. These beads are then conjugated with a specific antibody for the target ligand [220].
During magnetic activated cell sorting (MACS), specific binding to the target cell structure occurs, these structures flow through a magnetic column and the targeted cells remain in the column. After washing to eliminate the nonmagnetically bound cells, the selected, magnetically bound cells can be acquired in another step by removing the magnetic field [216].

During magnetofection (MF), nanoparticle-associated vector DNA is transfected by an external magnetic field to cells $[217,221]$. The association of the negatively charged DNA is achieved by a positive surface charge of the nanoparticles via polycationic polyethylenimine. It was able to be shown that the effectiveness of the vector transfection can be increased several thousand times with only a minimal increase in toxicity $[217,222]$.

\section{Diagnostic magnetic resonance (DMR)}

Further applications of magnetic nanoparticles (MNP) with a high potential for further clinical diagnostics describe the in vitro use of targeted MNP or SPIO in quantitative diagnostic magnetic resonance (DMR) for the highly sensitive detection of biomarkers [223] (DNA, mRNA, proteins, small molecules, enzymes, medications), pathogens (viruses [224], bacteria [225]), or cells (tumor cells [226]), circulating immune/tumor cells [227]) under modulation of the T2 relaxation of biological samples.

Using miniaturized, chip-based DMR detector systems, it was able to be shown that highly sensitive, multiple DMR measurements can be performed using sample volumes of only several microliters $(<10 \mu \mathrm{l})$ [223]. Using portable micro-NMR ( $\mu$ NMR) $[225,227]$, it was able to be shown that this new diagnostic bedside technology can be used similarly to the principle of immunohistochemistry to analyze cell samples from tumors directly after acquisition (e.g. fineneedle aspiration) via specific, CLIO-labeled antibodies for a defined number of surface proteins (e.g. EpCAM (epithelial cell adhesion molecule), MUC-1 (mucin 1), HER2, EGFR, B7-H3, CK18, Ki-67, p53, vimentin). However, in contrast to conventional immunohistochemistry, a cell analysis can be performed in significantly less time (15-60 min.) with this method. In a clinical study on 70 test subjects with abdominal carcinomas, Haun et al. [226] were able to show that this still experimental-preclinical method can detect tumor cells with an accuracy of $96 \%$ using a 4-protein signature (MUC-1 +EGFR+HER2 +EpCAM), that protein signatures of tumor cells depend on the extraction site within the tumors (tumor heterogeneity), and the signature can change from the time of sampling to cytological analysis making it necessary to perform real-time analysis. In clinical application, this method could make it possible to perform real-time analyses of tumor or blood cells directly ex vivo after sampling so that therapeutic treatment strategies can be introduced more quickly and can be better tailored to the in vivo situation.

Advantages of MNP-based analysis methods versus conventional ones could be the low intrinsic (background) magnetization of biological samples, the highly sensitive measurability of MNPs, and the short sample preparation time. Moreover, compared to optical techniques, DMR is not subject to interference such as light scattering, absorption, auto-fluorescence, or time-consuming sample preparation steps [223]. 


\section{Magnetic particle imaging (MPI)}

A new imaging modality using SPIO is magnetic particle imaging (MPI) [27]. This new radiation-free tomographic imaging method provides background-free, directly quantifiable information about the spatial distribution of SPIO with a high temporal resolution (milliseconds), spatial resolution $(<1 \mathrm{~mm})$, and sensitivity $(\mu \mathrm{mol})$ [228]. Feasibility in living organisms was able to be shown in initial preclinical studies [229]. Moreover, with optimization of the SPIO (currently often Resovist ${ }^{\circledR}$ ) and the equipment hardware, this technology has the potential to image nanomolar and picomolar concentrations of SPIO [230], making the application thereof in molecular imaging interesting. Using the currently available SPIO, similar application areas as in MRI combined with higher spatial and temporal resolution and better sensitivity are possible for this method. Potential MPI application areas include cardiovascular applications (angiographies, cardiac vitality diagnosis, tissue perfusion, plaque labeling, endovascular interventions, bleeding source diagnosis) or applications in tumor, molecular, and cellular imaging (passive and active targeting, molecular therapies, cellular labeling and cell monitoring) [231]. The advantages and disadvantages of this imaging method and possible clinical application areas will soon be demonstrated by an initiative of the German Research Foundation to install MPI small animal scanners and evaluate them in various disease entities.

\section{Conclusion and outlook}

\section{$\nabla$}

Since MRI is an integral part of today's clinical diagnosis of diseases, the search for suitable and targeted contrast agents has driven the development and use of SPIO. The major advances in materials research, nanotechnology, and conjugation chemistry have continuously expanded the application spectrum of SPIO in preclinical-experimental imaging in recent years. This is no longer limited to macroscopic-anatomical imaging using SPIO and is now also being applied to cellular and molecular imaging. The advantage of MRI in this regard is the simultaneous recording of anatomical, cellular, and molecular information. Due to the large surface and the chemically defined surface structure, SPIO can be conjugated with numerous molecules or functionalized (targeting molecules) and loaded with fluorescent dyes, radioisotopes, and therapeutic agents. The use of monodisperse SPIO with more precise physicochemical and pharmacodynamic characteristics could allow more exact addressing of target structures and more exact parametric or quantitative SPIO-MRI. The thus synthesized nanoparticles have the potential to revolutionize medical treatment and therapy in the coming years with improved early detection, multimodal imaging, and synchronous treatment and diagnostics (theranostics). Moreover, highly sensitive MR nanoprobes can be helpful in cell therapy concepts such as the transplantation of stem cells, islet cells, or immune cells since SPIO allow tracking of very small cell quantities in an organism. The use of highly specific MNP probes in MACS for magnetofection or in particular in chip-based $\mu$ NMRs in diagnostic magnetic resonance (DMR) for the analysis of biological (patient) samples (e.g. biopsies) with respect to biomarkers, pathogens, or (tumor) cells could decisively expand the conventional method spectrum with respect to cell analysis (FACS, immunohistochemistry). MPI as a new imaging method currently being tested has the potential to open up a completely new spectrum in the application of SPIO in the case of successful evaluation in preclinical disease models.

It is currently still unclear whether the numerous SPIO constructs/conjugates successfully tested in preclinical models can fulfill the requirements of clinical application in the future and can prove their additional (compared to T1 contrast agent) or special benefit in MRI, DMR or MPI and this will remain the subject of research for the coming years and decades. In particular, questions regarding the safety profile of SPIO and SPIO conjugates, their pharmacokinetics and long-term toxicity, and the core as well as coating materials must be answered to ensure safe application of these nanoparticles in humans.

\section{References}

1 Bean CP. Magnetic Granulometry and Superparamagnetism. J Appl Phys 1956; 27: 1448 - 1452

2 Bean CP, Livingston JD. Superparamagnetism. J Appl Phys 1959; 30: $120-129$

3 Néel $L$. Théorie du trânage magnétique des ferromagnétiques en grains fins avec applications aux terres cuites. Ann Géophys 1949; 5: 99-136

4 Schoonmann J. Nanostructured materials in solid state ionics. Solid State Ionics 2000; 135: 5-19

5 Kemshead JT, Ugelstad J. Magnetic separation techniques: their application to medicine. Mol Cell Biochem 1985; 67: 11-18

6 Josephson L, Lewis J, Jacobs P et al. The effects of iron oxides on proton relaxivity. Magn Reson Imaging 1988; 6: 647-653

7 Hemmingsson A, Carlsten J, Ericsson A et al. Relaxation enhancement of the dog liver and spleen by biodegradable superparamagnetic particles in proton magnetic resonance imaging. Acta Radiol 1987; 28: $703-705$

8 Weissleder R, Elizondo G, Wittenberg J et al. Ultrasmall superparamagnetic iron oxide: an intravenous contrast agent for assessing lymph nodes with MR imaging. Radiology 1990; 175: 494-498

9 Seneterre E, Weissleder R, Jaramillo D et al. Bone marrow: ultrasmall superparamagnetic iron oxide for MR imaging. Radiology 1991; 179: 529-533

10 Stillman $A E$, Wilke $N$, Li D et al. Ultrasmall superparamagnetic iron oxide to enhance MRA of the renal and coronary arteries: studies in human patients. J Comput Assist Tomogr 1996; 20: $51-55$

11 Schmitz SA, Coupland SE, Gust R et al. Superparamagnetic iron oxideenhanced MRI of atherosclerotic plaques in Watanabe hereditable hyperlipidemic rabbits. Invest Radiol 2000; 35: 460-471

12 Schmitz SA, Winterhalter S, Schiffler S et al. USPIO-enhanced direct MR imaging of thrombus: preclinical evaluation in rabbits. Radiology 2001; 221: 237-243

13 Hahn PF, Stark DD, Weissleder R et al. Clinical application of superparamagnetic iron oxide to MR imaging of tissue perfusion in vascular liver tumors. Radiology 1990; 174: 361 - 366

14 Canet E, Revel D, Forrat $R$ et al. Superparamagnetic iron oxide particles and positive enhancement for myocardial perfusion studies assessed by subsecond T1-weighted MRI. Magn Reson Imaging 1993; 11: 1139-1145

15 Trillaud H, Grenier N, Degreze P et al. First-pass evaluation of renal perfusion with TurboFLASH MR imaging and superparamagnetic iron oxide particles. J Magn Reson Imaging 1993; 3: 83-91

16 Kent TA, Quast MJ, Kaplan BJ et al. Assessment of a superparamagnetic iron oxide (AMI-25) as a brain contrast agent. Magn Reson Med 1990; 13: $434-443$

17 Bradley RH, Kent TA, Eisenberg HM et al. Middle cerebral artery occlusion in rats studied by magnetic resonance imaging. Stroke 1989; 20: 1032-1036

18 Deloison B, Siauve N, Aimot S et al. SPIO-enhanced magnetic resonance imaging study of placental perfusion in a rat model of intrauterine growth restriction. BJOG 2012; 119: 626-633 
19 Reiner CS, Lutz AM, Tschirch F et al. USPIO-enhanced magnetic resonance imaging of the knee in asymptomatic volunteers. Eur Radiol 2009; 19: $1715-1722$

20 Lewin $\mathrm{M}$, Carlesso $\mathrm{N}$, Tung $\mathrm{CH}$ et al. Tat peptide-derivatized magnetic nanoparticles allow in vivo tracking and recovery of progenitor cells. Nat Biotechnol 2000; 18: $410-414$

21 Bulte JW, Douglas T, Witwer B et al. Magnetodendrimers allow endosomal magnetic labeling and in vivo tracking of stem cells. Nat Biotechnol 2001; 19: 1141 - 1147

22 Islam T, Josephson L. Current state and future applications of active targeting in malignancies using superparamagnetic iron oxide nanoparticles. Cancer Biomark 2009; 5: 99-107

23 Yu Y, Sun D. Superparamagnetic iron oxide nanoparticle "theranostics" for multimodality tumor imaging, gene delivery, targeted drug and prodrug delivery. Expert Rev Clin Pharmacol 2010; 3: 117-130

24 Jordan A, Scholz R, Maier-Hauff $K$ et al. The effect of thermotherapy using magnetic nanoparticles on rat malignant glioma. J Neurooncol 2006; 78: 7-14

25 Bruns OT, Ittrich $H$, Peldschus $K$ et al. Real-time magnetic resonance imaging and quantification of lipoprotein metabolism in vivo using nanocrystals. Nat Nanotechnol 2009; 4: 193 -201

26 Bartelt A, Bruns OT, Reimer $R$ et al. Brown adipose tissue activity controls triglyceride clearance. Nat Med 2011; 17: 200 - 205

27 Gleich $B$, Weizenecker J. Tomographic imaging using the nonlinear response of magnetic particles. Nature 2005; 435: 1214-1217

28 Taupitz M, Schmitz S, Hamm B. Superparamagnetic iron oxide particles: current state and future development. Fortschr Röntgenstr 2003; 175: $752-765$

29 Bulte JW, Kraitchman DL. Iron oxide MR contrast agents for molecular and cellular imaging. NMR Biomed 2004; 17: 484-499

30 Dodd SJ, Williams M, Suhan JP et al. Detection of single mammalian cells by high-resolution magnetic resonance imaging. Biophys J 1999; 76: $103-109$

31 Haacke EM, Xu Y, Cheng YC et al. Susceptibility weighted imaging (SWI). Magn Reson Med 2004; 52: 612-618

32 Haacke EM, Mittal S, Wu Z et al. Susceptibility-weighted imaging: technical aspects and clinical applications, part 1. Am J Neuroradiol 2009; 30: $19-30$

33 Mittal S, Wu Z, Neelavalli J et al. Susceptibility-weighted imaging: technical aspects and clinical applications, part 2. Am J Neuroradiol 2009; 30: $232-252$

34 Eibofner F, Steidle G, Kehlbach $R$ et al. Positive contrast imaging of iron oxide nanoparticles with susceptibility-weighted imaging. Magn Reson Med 2010; 64: 1027-1038

35 Zhao Q Langley J, Lee $S$ et al. Positive contrast technique for the detection and quantification of superparamagnetic iron oxide nanoparticles in MRI. NMR Biomed 2011; 24: 464-472

36 Dahnke H, Liu W, Herzka $D$ et al. Susceptibility gradient mapping (SGM): a new postprocessing method for positive contrast generation applied to superparamagnetic iron oxide particle (SPIO)-labeled cells. Magn Reson Med 2008; 60: 595-603

37 Massart R, Cabuil V. Effect of some parameters on the formation of colloidal magnetite in alkaline medium - yield and particle-size control. Journal of Chemical Physics 1987; 84: 967-973

38 Sun S, Zeng $H$. Size-controlled synthesis of magnetite nanoparticles. J Am Chem Soc 2002; 124: $8204-8205$

39 Park J, An K, Hwang $Y$ et al. Ultra-large-scale syntheses of monodisperse nanocrystals. Nat Mater 2004; 3: 891 - 895

40 Wang YX, Hussain SM, Krestin GP. Superparamagnetic iron oxide contrast agents: physicochemical characteristics and applications in MR imaging. Eur Radiol 2001; 11: 2319-2331

41 Shen $T$, Weissleder R, Papisov $M$ et al. Monocrystalline iron oxide nanocompounds (MION): physicochemical properties. Magn Reson Med 1993; 29: $599-604$

42 Taupitz M, Schnorr J, Abramjuk C et al. New generation of monomerstabilized very small superparamagnetic iron oxide particles (VSOP) as contrast medium for MR angiography: preclinical results in rats and rabbits. J Magn Reson Imaging 2000; 12: 905 - 911

43 Wagner S, Schnorr J, Pilgrimm H et al. Monomer-coated very small superparamagnetic iron oxide particles as contrast medium for magnetic resonance imaging: preclinical in vivo characterization. Invest Radiol 2002; 37: 167 - 177

44 Schnorr J, Wagner S, Pilgrimm $H$ et al. Preclinical characterization of monomer-stabilized very small superparamagnetic iron oxide parti- cles (VSOP) as a blood pool contrast medium for MR angiography. Acad Radiol 2002; 9: S307 - S309

45 Wunderbaldinger $P$, Josephson L, Weissleder $R$. Crosslinked iron oxides (CLIO): a new platform for the development of targeted MR contrast agents. Acad Radiol 2002; 9: S304-S306

46 Senpan A, Caruthers SD, Rhee I et al. Conquering the dark side: colloidal iron oxide nanoparticles. ACS Nano 2009; 3: 3917-3926

47 Gupta AK, Wells S. Surface-modified superparamagnetic nanoparticles for drug delivery: preparation, characterization, and cytotoxicity studies. IEEE Trans Nanobioscience 2004; 3: 66-73

48 Chouly C, Pouliquen D, Lucet I et al. Development of superparamagnetic nanoparticles for MRI: effect of particle size, charge and surface nature on biodistribution. J Microencapsul 1996; 13: 245 - 255

49 Laurent S, Bridot JL, Elst LV et al. Magnetic iron oxide nanoparticles for biomedical applications. Future Med Chem 2010; 2: 427-449

50 Gupta AK, Gupta M. Synthesis and surface engineering of iron oxide nanoparticles for biomedical applications. Biomaterials 2005; 26 : $3995-4021$

51 Lunov 0 , Syrovets $T$, Rocker $C$ et al. Lysosomal degradation of the carboxydextran shell of coated superparamagnetic iron oxide nanoparticles and the fate of professional phagocytes. Biomaterials 2010; 31 : 9015-9022

52 Weissleder R, Bogdanov A, Neuwelt EA et al. Long-circulating iron oxides for MR imaging. Advanced Drug Delivery Reviews 1995; 16: 321 - 334

53 Corot $C$, Robert $P$, Idee JM et al. Recent advances in iron oxide nanocrystal technology for medical imaging. Adv Drug Deliv Rev 2006; 58: $1471-1504$

54 Gupta AK, Curtis AS. Surface modified superparamagnetic nanoparticles for drug delivery: interaction studies with human fibroblasts in culture. J Mater Sci Mater Med 2004; 15: 493 - 496

55 Schafer R, Kehlbach R, Wiskirchen J et al. Transferrin receptor upregulation: in vitro labeling of rat mesenchymal stem cells with superparamagnetic iron oxide. Radiology 2007; 244: 514- 523

56 Freund B, Tromsdorf UI, Bruns OT et al. A simple and widely applicable method to (59)fe-radiolabel monodisperse superparamagnetic iron oxide nanoparticles for in vivo quantification studies. ACS Nano 2012; 6: $7318-7325$

57 Gibson N, Holzwarth U, Abbas K et al. Radiolabelling of engineered nanoparticles for in vitro and in vivo tracing applications using cyclotron accelerators. Arch Toxicol 2011; 85: 751 - 773

58 Natarajan A, Gruettner C, Ivkov $R$ et al. NanoFerrite particle based radioimmunonanoparticles: binding affinity and in vivo pharmacokinetics. Bioconjug Chem 2008; 19: $1211-1218$

59 Glaus $C$, Rossin $R$, Welch $M$ J et al. In vivo evaluation of (64)Cu-labeled magnetic nanoparticles as a dual-modality PET/MR imaging agent. Bioconjug Chem 2010; 21: 715-722

60 de Torres MR R, Tavare R, Glaria A et al. 99mTC-bisphosphonate-iron oxide nanoparticle conjugates for dual-modality biomedical imaging. Bioconjug Chem 2011; 22: 455 - 465

61 Anzai $Y$, Piccoli CW, Outwater EK et al. Evaluation of neck and body metastases to nodes with ferumoxtran 10-enhanced MR imaging: phase III safety and efficacy study. Radiology 2003; 228: 777 - 788

62 Weissleder $R$, Stark DD, Engelstad BL et al. Superparamagnetic iron oxide: pharmacokinetics and toxicity. Am J Roentgenol 1989; 152: $167-173$

63 Bourrinet $P$, Bengele $H H$, Bonnemain $B$ et al. Preclinical safety and pharmacokinetic profile of ferumoxtran-10, an ultrasmall superparamagnetic iron oxide magnetic resonance contrast agent. Invest Radiol 2006; 41: $313-324$

64 Kawamori Y, Matsui O, Kadoya M et al. Differentiation of hepatocellular carcinomas from hyperplastic nodules induced in rat liver with ferriteenhanced MR imaging. Radiology 1992; 183: 65-72

65 Ferrucci JT, Stark DD. Iron oxide-enhanced MR imaging of the liver and spleen: review of the first 5 years. Am J Roentgenol 1990; 155: 943 950

66 Imai Y, Murakami T, Yoshida S et al. Superparamagnetic iron oxide-enhanced magnetic resonance images of hepatocellular carcinoma: correlation with histological grading. Hepatology 2000; 32: $205-212$

67 Takeshita K, Nagashima I, Frui S et al. Effect of superparamagnetic iron oxide-enhanced MRI of the liver with hepatocellular carcinoma and hyperplastic nodule. J Comput Assist Tomogr 2002; 26: 451 - 455

$68 \mathrm{Vogl} \mathrm{TJ}$, Hammerstingl $\mathrm{R}$, Keck $\mathrm{H}$ et al. Differential diagnosis of focal liver lesions with MRI using the superparamagnetic contrast medium endorem. Radiologe 1995; 35: S258-S266 
69 Vogl TJ, Hammerstingl R, Schwarz W et al. Magnetic resonance imaging of focal liver lesions. Comparison of the superparamagnetic iron oxide resovist versus gadolinium-DTPA in the same patient. Invest Radiol 1996; 31: 696-708

$70 \mathrm{Kim}$ YK, Kim CS, Han YM et al. Comparison of gadoxetic acid-enhanced MRI and superparamagnetic iron oxide-enhanced MRI for the detection of hepatocellular carcinoma. Clin Radiol 2010; 65: 358-365

71 Neuwelt EA, Hamilton BE, Varallyay CG et al. Ultrasmall superparamagnetic iron oxides (USPIOs): a future alternative magnetic resonance (MR) contrast agent for patients at risk for nephrogenic systemic fibrosis (NSF)? Kidney Int 2009; 75: 465 - 474

72 Rodriguez E, Netto G, Li QK. Intrapancreatic accessory spleen: A case report and review of literature. Diagn Cytopathol 2012; 41: 466 - 469

73 Anzai Y, Prince MR. Iron oxide-enhanced MR lymphography: the evaluation of cervical lymph node metastases in head and neck cancer. J Magn Reson Imaging 1997; 7: 75-81

74 Stets C, Brandt S, Wallis F et al. Axillary lymph node metastases: a statistical analysis of various parameters in MRI with USPIO. J Magn Reson Imaging 2002; 16: 60-68

75 Nguyen $B C$, Stanford $W$, Thompson BH et al. Multicenter clinical trial of ultrasmall superparamagnetic iron oxide in the evaluation of mediastinal lymph nodes in patients with primary lung carcinoma. J Magn Reson Imaging 1999; 10: $468-473$

76 Pultrum BB, van der Jagt EJ, van Westreenen $H L$ et al. Detection of lymph node metastases with ultrasmall superparamagnetic iron oxide (USPIO)-enhanced magnetic resonance imaging in oesophageal cancer: a feasibility study. Cancer Imaging 2009; 9: 19-28

77 Tokuhara T, Tanigawa N, Matsuki M et al. Evaluation of lymph node metastases in gastric cancer using magnetic resonance imaging with ultrasmall superparamagnetic iron oxide (USPIO): diagnostic performance in post-contrast images using new diagnostic criteria. Gastric Cancer 2008; 11: 194-200

78 Koh DM, Brown G, Temple L et al. Rectal cancer: mesorectal lymph nodes at MR imaging with USPIO versus histopathologic findings-initial observations. Radiology 2004; 231: 91 -99

79 Harisinghani MG, Saini S, Slater GJ et al. MR imaging of pelvic lymph nodes in primary pelvic carcinoma with ultrasmall superparamagnetic iron oxide (Combidex): preliminary observations. J Magn Reson Imaging 1997; 7: $161-163$

80 Sigovan M, Boussel L, Sulaiman A et al. Rapid-clearance iron nanoparticles for inflammation imaging of atherosclerotic plaque: initial experience in animal model. Radiology 2009; 252: 401 -409

81 Hahn PF, Stark DD, Ferrucci JT. Accumulation of iron oxide particles around liver metastases during MR imaging. Gastrointest Radiol 1992; 17: $173-174$

82 Moore A, Marecos E, Bogdanov A et al. Tumoral distribution of long-circulating dextran-coated iron oxide nanoparticles in a rodent model. Radiology 2000; 214: 568 - 574

83 Zimmer C, Weissleder R, Poss K et al. MR imaging of phagocytosis in experimental gliomas. Radiology 1995; 197: 533-538

84 Kotoura N, Sakamoto K, Fukuda $Y$ et al. Evaluation of magnetic resonance signal intensity in bone marrow after administration of super paramagnetic iron oxide (SPIO). Nihon Hoshasen Gijutsu Gakkai Zasshi 2011; 67: $212-220$

85 Fukuda Y, Ando K, Ishikura R et al. Superparamagnetic iron oxide (SPIO) MRI contrast agent for bone marrow imaging: differentiating bone metastasis and osteomyelitis. Magn Reson Med Sci 2006; 5: 191 - 196

86 Herrmann KA, Zech CJ, Michaely HJ et al. Comprehensive magnetic resonance imaging of the small and large bowel using intraluminal dual contrast technique with iron oxide solution and water in magnetic resonance enteroclysis. Invest Radiol 2005; 40: 621-629

87 Frericks BB, Wacker F, Loddenkemper C et al. Magnetic resonance imaging of experimental inflammatory bowel disease: quantitative and qualitative analyses with histopathologic correlation in a rat model using the ultrasmall iron oxide SHU 555 C. Invest Radiol 2009; 44: $23-30$

88 Saleh A, Schroeter M, Jonkmanns C et al. In vivo MRI of brain inflammation in human ischaemic stroke. Brain 2004; 127: 1670-1677

89 Enochs WS, Harsh G, Hochberg $F$ et al. Improved delineation of human brain tumors on MR images using a long-circulating, superparamagnetic iron oxide agent. J Magn Reson Imaging 1999; 9: 228 - 232

90 Vellinga MM, Oude ERD, Seewann A et al. Pluriformity of inflammation in multiple sclerosis shown by ultra-small iron oxide particle enhancement. Brain 2008; 131: 800-807
91 Weinstein JS, Varallyay CG, Dosa E et al. Superparamagnetic iron oxide nanoparticles: diagnostic magnetic resonance imaging and potential therapeutic applications in neurooncology and central nervous system inflammatory pathologies, a review. J Cereb Blood Flow Metab 2010; 30: $15-35$

92 Saleh A, Schroeter M, Ringelstein A et al. Iron oxide particle-enhanced MRI suggests variability of brain inflammation at early stages after ischemic stroke. Stroke 2007; 38: 2733-2737

93 Ruehm SG, Corot C, Vogt P et al. Magnetic resonance imaging of atherosclerotic plaque with ultrasmall superparamagnetic particles of iron oxide in hyperlipidemic rabbits. Circulation 2001; 103: 415-422

94 Kooi ME, Cappendijk VC, Cleutjens KB et al. Accumulation of ultrasmall superparamagnetic particles of iron oxide in human atherosclerotic plaques can be detected by in vivo magnetic resonance imaging. Circulation 2003; 107: $2453-2458$

95 Corot C, Petry KG, Trivedi R et al. Macrophage imaging in central nervous system and in carotid atherosclerotic plaque using ultrasmall superparamagnetic iron oxide in magnetic resonance imaging. Invest Radiol 2004; 39: 619-625

96 Ahlstrom KH, Johansson LO, Rodenburg JB et al. Pulmonary MR angiography with ultrasmall superparamagnetic iron oxide particles as a blood pool agent and a navigator echo for respiratory gating: pilot study. Radiology 1999; 211: 865-869

97 Nolte-Ernsting C, Adam G, Bucker A et al. Abdominal MR angiography performed using blood pool contrast agents: comparison of a new superparamagnetic iron oxide nanoparticle and a linear gadolinium polymer. Am J Roentgenol 1998; 171: 107-113

98 Wagner M, Wagner S, Schnorr J et al. Coronary MR angiography using citrate-coated very small superparamagnetic iron oxide particles as blood-pool contrast agent: initial experience in humans. J Magn Reson Imaging 2011; 34: 816-823

99 Schnorr J, Taupitz M, Schellenberger EA et al. Cardiac magnetic resonance angiography using blood-pool contrast agents: comparison of citrate-coated very small superparamagnetic iron oxide particles with gadofosveset trisodium in pigs. Fortschr Röntgenstr 2012; 184: $105-112$

100 Knollmann FD, BockJC, Teltenkotter S et al. Evaluation of portal MR angiography using superparamagnetic iron oxide. J Magn Reson Imaging 1997; 7: $191-196$

101 Ono Y, Marukawa T, Ashikaga $R$ et al. Three-dimensional MR angiography of HCC and portal and hepatic veins using superparamagnetic iron oxide. Nihon Igaku Hoshasen Gakkai Zasshi 1998; 58: 97-98

102 Tanimoto A, Yuasa Y, Hiramatsu K. Enhancement of phase-contrast MR angiography with superparamagnetic iron oxide. J Magn Reson Imaging 1998; 8: 446-450

103 Schmitz SA, Albrecht T, Wolf KJ. MR angiography with superparamagnetic iron oxide: feasibility study. Radiology 1999; 213: 603-607

104 Lanzman RS, Schmitt P, Kropil P et al. Nonenhanced MR angiography techniques. Fortschr Röntgenstr 2011; 183: 913-924

105 Turetschek K, Huber S, Helbich T et al. Dynamic MRI enhanced with albumin-(Gd-DTPA)30 or ultrasmall superparamagnetic iron oxide particles (NC100150 injection) for the measurement of microvessel permeability in experimental breast tumors. Acad Radiol 2002; 9: S112-S114

106 Persigehl T, Wall A, Kellert J et al. Tumor blood volume determination by using susceptibility-corrected DeltaR2* multiecho MR. Radiology 2010; 255: 781-789

107 Persigehl T, Bieker R, Matuszewski L et al. Antiangiogenic tumor treatment: early noninvasive monitoring with USPIO-enhanced MR imaging in mice. Radiology 2007; 244: 449-456

108 Kaufels N, Korn R, Wagner S et al. Magnetic resonance imaging of liver metastases: experimental comparison of anionic and conventional superparamagnetic iron oxide particles with a hepatobiliary contrast medium during dynamic and uptake phases. Invest Radiol 2008; 43: 496-503

109 Bachmann R, Conrad R, Kreft B et al. Evaluation of a new ultrasmall superparamagnetic iron oxide contrast agent Clariscan, (NC100150) for MRI of renal perfusion: experimental study in an animal model. J Magn Reson Imaging 2002; 16: 190-195

110 Rudin $M$, Rausch $M$, Stoeckli $M$. Molecular imaging in drug discovery and development: potential and limitations of nonnuclear methods. Mol Imaging Biol 2005; $7: 5-13$

111 Hudson PJ, Souriau C. Engineered antibodies. Nat Med 2003; 9: 129 134 
112 Neumaier CE, Baio G, Ferrini S et al. MR and iron magnetic nanoparticles. Imaging opportunities in preclinical and translational research. Tumori 2008; 94: 226-233

113 Kelly KA, Allport JR, Tsourkas A et al. Detection of vascular adhesion molecule-1 expression using a novel multimodal nanoparticle. Circ Res 2005; 96: $327-336$

114 Artemov D, Mori N, Okollie B et al. MR molecular imaging of the Her-2/ neu receptor in breast cancer cells using targeted iron oxide nanoparticles. Magn Reson Med 2003; 49: 403 - 408

115 Kresse M, Wagner S, Pfefferer D et al. Targeting of ultrasmall superparamagnetic iron oxide (USPIO) particles to tumor cells in vivo by using transferrin receptor pathways. Magn Reson Med 1998; 40: 236-242

116 Konda SD, Aref M, Wang S et al. Specific targeting of folate-dendrimer MRI contrast agents to the high affinity folate receptor expressed in ovarian tumor xenografts. MAGMA 2001; 12: 104-113

117 Hsieh WJ, Liang CJ, Chieh JJ et al. In vivo tumor targeting and imaging with anti-vascular endothelial growth factor antibody-conjugated dextran-coated iron oxide nanoparticles. Int J Nanomedicine 2012; 7: $2833-2842$

118 Zhang C, Jugold M, Woenne EC et al. Specific targeting of tumor angiogenesis by RGD-conjugated ultrasmall superparamagnetic iron oxide particles using a clinical 1.5-T magnetic resonance scanner. Cancer Res 2007; 67: 1555-1562

119 Kiessling F, Huppert J, Zhang C et al. RGD-labeled USPIO inhibits adhesion and endocytotic activity of alpha $\mathrm{v}$ beta3-integrin-expressing glioma cells and only accumulates in the vascular tumor compartment. Radiology 2009; 253: 462 - 469

120 Moore A, Medarova Z, Potthast A et al. In vivo targeting of underglycosylated MUC-1 tumor antigen using a multimodal imaging probe. Cancer Res 2004; 64: 1821 - 1827

121 Leuschner C, Kumar CS, Hansel $W$ et al. LHRH-conjugated magnetic iron oxide nanoparticles for detection of breast cancer metastases. Breast Cancer Res Treat 2006; 99: 163-176

122 Chopra A. Single-chain anti-epidermal growth factor receptor antibody fragment conjugated to magnetic iron oxide nanoparticles; 2004, s. Anhang - aus Molecular Imaging and Contrast Database (MICAD), Internet

123 Vigor KL, Kyrtatos PG, Minogue S et al. Nanoparticles functionalized with recombinant single chain $\mathrm{Fv}$ antibody fragments ( $\mathrm{scFv}$ ) for the magnetic resonance imaging of cancer cells. Biomaterials 2010; 31 : $1307-1315$

124 Poselt E, Schmidtke C, Fischer S et al. Tailor-made quantum dot and iron oxide based contrast agents for in vitro and in vivo tumor imaging. ACS Nano 2012; 6: 3346-3355

$125 \mathrm{He} Y$, Song W, Lei J et al. Anti-CXCR4 monoclonal antibody conjugated to ultrasmall superparamagnetic iron oxide nanoparticles in an application of MR molecular imaging of pancreatic cancer cell lines. Acta Radiol 2012; 53: 1049-1058

126 Cheng KT. Ultrasmall superparamagnetic iron oxide-anti-CD20 monoclonal antibody; 2004, s. Anhang - aus Molecular Imaging and Contrast Database (MICAD), Internet

127 Luchetti A, Milani D, Ruffini F et al. Monoclonal Antibodies Conjugated with Superparamagnetic Iron Oxide Particles Allow Magnetic Resonance Imaging Detection of Lymphocytes in the Mouse Brain. Mol Imaging 2011, s. Anhang (Epub ahead of print)

128 Reimer P, Weissleder R, Lee AS et al. Receptor imaging: application to MR imaging of liver cancer. Radiology 1990; 177: 729-734

129 Reimer $P$, Weissleder $R$, Shen $T$ et al. Pancreatic receptors: initial feasibility studies with a targeted contrast agent for MR imaging. Radiology 1994; 193: $527-531$

130 Zhao M, Beauregard DA, Loizou $L$ et al. Non-invasive detection of apoptosis using magnetic resonance imaging and a targeted contrast agent. Nat Med 2001; 7: $1241-1244$

131 Schellenberger EA, Hogemann D, Josephson L et al. Annexin V-CLIO: a nanoparticle for detecting apoptosis by MRI. Acad Radiol 2002; 9: S310-S311

132 Schellenberger E, Schnorr J, Reutelingsperger C et al. Linking proteins with anionic nanoparticles via protamine: ultrasmall protein-coupled probes for magnetic resonance imaging of apoptosis. Small 2008; 4: $225-230$

133 Smith BR, Heverhagen J, Knopp M et al. Localization to atherosclerotic plaque and biodistribution of biochemically derivatized superparamagnetic iron oxide nanoparticles (SPIONs) contrast particles for magnetic resonance imaging (MRI). Biomed Microdevices 2007; 9: $719-727$
134 Briley-Saebo KC, Cho YS, Shaw PX et al. Targeted iron oxide particles for in vivo magnetic resonance detection of atherosclerotic lesions with antibodies directed to oxidation-specific epitopes. J Am Coll Cardiol 2011; 57: 337-347

$135 \mathrm{Tu} \mathrm{C}, \mathrm{Ng} \mathrm{TS}$, Sohi HK et al. Receptor-targeted iron oxide nanoparticles for molecular MR imaging of inflamed atherosclerotic plaques. Biomaterials 2011; 32: 7209 - 7216

136 McAteer MA, Akhtar AM, von Zur MuhlenC et al. An approach to molecular imaging of atherosclerosis, thrombosis, and vascular inflammation using microparticles of iron oxide. Atherosclerosis 2010; 209: $18-27$

137 Wen S, Liu DF, Liu Z et al. OxLDL-targeted iron oxide nanoparticles for in vivo MRI detection of perivascular carotid collar induced atherosclerotic lesions in ApoE-deficient mice. J Lipid Res 2012; 53: 829838

138 Weissleder R, Lee AS, Khaw BA et al. Antimyosin-labeled monocrystalline iron oxide allows detection of myocardial infarct: MR antibody imaging. Radiology 1992; 182: 381 - 385

139 Johansson LO, Bjornerud A, Ahlstrom HK et al. A targeted contrast agent for magnetic resonance imaging of thrombus: implications of spatial resolution. J Magn Reson Imaging 2001; 13: 615-618

140 Duerschmied D, Meissner M, Peter $K$ et al. Molecular magnetic resonance imaging allows the detection of activated platelets in a new mouse model of coronary artery thrombosis. Invest Radiol 2011; 46: 618-623

141 Ariens RA, Lai TS, Weisel JW et al. Role of factor XIII in fibrin clot formation and effects of genetic polymorphisms. Blood 2002; 100: $743-754$

142 Bulte JW, Ma LD, Magin RL et al. Selective MR imaging of labeled human peripheral blood mononuclear cells by liposome mediated incorporation of dextran-magnetite particles. Magn Reson Med 1993; 29: $32-37$

143 Bulte JW, Laughlin PG, Jordan EK et al. Tagging of T cells with superparamagnetic iron oxide: uptake kinetics and relaxometry. Acad Radiol 1996; 3: S301-S303

144 Bulte JW, Ben-Hur T, Miller BR et al. MR microscopy of magnetically labeled neurospheres transplanted into the Lewis EAE rat brain. Magn Reson Med 2003; 50: 201-205

145 Josephson L, Tung CH, Moore A et al. High-efficiency intracellular magnetic labeling with novel superparamagnetic-Tat peptide conjugates. Bioconjug Chem 1999; 10: 186-191

146 Frank JA, Zywicke H, Jordan EK et al. Magnetic intracellular labeling of mammalian cells by combining (FDA-approved) superparamagnetic iron oxide MR contrast agents and commonly used transfection agents. Acad Radiol 2002; 9: S484-A487

147 Bulte JW, Douglas T, Witwer B et al. Magnetodendrimers allow endosomal magnetic labeling and in vivo tracking of stem cells. Nat Biotechnol 2001; 19: 1141 - 1147

148 Arbab AS, Bashaw LA, Miller BR et al. Intracytoplasmic tagging of cells with ferumoxides and transfection agent for cellular magnetic resonance imaging after cell transplantation: methods and techniques. Transplantation 2003; 76: 1123-1130

149 Frank JA, Miller BR, Arbab AS et al. Clinically applicable labeling of mammalian and stem cells by combining superparamagnetic iron oxides and transfection agents. Radiology 2003; 228: 480-487

150 Crabbe A, Vandeputte C, Dresselaers T et al. Effects of MRI contrast agents on the stem cell phenotype. Cell Transplant 2010; 19: 919-936

151 Arbab AS, Yocum GT, Rad AM et al. Labeling of cells with ferumoxidesprotamine sulfate complexes does not inhibit function or differentiation capacity of hematopoietic or mesenchymal stem cells. NMR Biomed 2005; 18: 553 - 559

152 Schafer R, Kehlbach R, Muller M et al. Labeling of human mesenchymal stromal cells with superparamagnetic iron oxide leads to a decrease in migration capacity and colony formation ability. Cytotherapy 2009; $11: 68-78$

153 Naqvi S, Samim M, Abdin M et al. Concentration-dependent toxicity of iron oxide nanoparticles mediated by increased oxidative stress. Int J Nanomedicine 2010; 5: 983 -989

154 Chen YC, Hsiao JK, Liu HM et al. The inhibitory effect of superparamagnetic iron oxide nanoparticle (Ferucarbotran) on osteogenic differentiation and its signaling mechanism in human mesenchymal stem cells. Toxicol Appl Pharmacol 2010; 245: 272 - 279

155 Schafer R, Ayturan M, Bantleon $R$ et al. The use of clinically approved small particles of iron oxide (SPIO) for labeling of mesenchymal stem cells aggravates clinical symptoms in experimental autoimmune en- 
cephalomyelitis and influences their in vivo distribution. Cell Transplant 2008; 17: 923-941

156 Karussis D, Karageorgiou C, Vaknin-Dembinsky A et al. Safety and immunological effects of mesenchymal stem cell transplantation in patients with multiple sclerosis and amyotrophic lateral sclerosis. Arch Neurol 2010; 67: 1187-1194

157 Politi LS, Bacigaluppi M, Brambilla E et al. Magnetic-resonance-based tracking and quantification of intravenously injected neural stem cell accumulation in the brains of mice with experimental multiple sclerosis. Stem Cells 2007; 25: 2583-2592

158 Kustermann E, Roell W, Breitbach $M$ et al. Stem cell implantation in ischemic mouse heart: a high-resolution magnetic resonance imaging investigation. NMR Biomed 2005; 18: $362-370$

159 Bos C, Delmas Y, Desmouliere A et al. In vivo MR imaging of intravascularly injected magnetically labeled mesenchymal stem cells in rat kidney and liver. Radiology 2004; 233: 781 - 789

160 Daldrup-Link HE, Rudelius M, Piontek G et al. Migration of iron oxidelabeled human hematopoietic progenitor cells in a mouse model: in vivo monitoring with 1.5-T MR imaging equipment. Radiology 2005; 234: $197-205$

161 Ittrich $H$, Lange $C$, Togel $F$ et al. In vivo magnetic resonance imaging of iron oxide-labeled, arterially-injected mesenchymal stem cells in kidneys of rats with acute ischemic kidney injury: detection and monitoring at 3T. J Magn Reson Imaging 2007; 25: 1179-1191

162 van Buul GM, Kotek G, Wielopolski PA et al. Clinically translatable cell tracking and quantification by MRI in cartilage repair using superparamagnetic iron oxides. PLoS One 2011; 6: e17001

163 Cahill KS, Gaidosh G, Huard J et al. Noninvasive monitoring and tracking of muscle stem cell transplants. Transplantation 2004; 78: 1626-1633

164 Arbab AS, Pandit SD, Anderson SA et al. Magnetic resonance imaging and confocal microscopy studies of magnetically labeled endothelial progenitor cells trafficking to sites of tumor angiogenesis. Stem Cells 2006; 24: $671-678$

165 Toso C, Vallee JP, Morel $P$ et al. Clinical magnetic resonance imaging of pancreatic islet grafts after iron nanoparticle labeling. Am J Transplant 2008; 8: $701-706$

166 Daldrup-Link HE, Meier R, Rudelius $M$ et al. In vivo tracking of genetically engineered, anti-HER2/neu directed natural killer cells to HER2/ neu positive mammary tumors with magnetic resonance imaging. Eur Radiol 2005; 15: 4-13

167 Khurana A, Nejadnik H, Gawande R et al. Intravenous Ferumoxytol Allows Noninvasive MR Imaging Monitoring of Macrophage Migration into Stem Cell Transplants. Radiology 2012; 264: 803-811

168 Daldrup-Link HE, Golovko D, Ruffell B et al. MRI of tumor-associated macrophages with clinically applicable iron oxide nanoparticles. Clin Cancer Res 2011; 17: 5695-5704

169 Truijers M, Futterer JJ, Takahashi S et al. In vivo imaging of the aneurysm wall with MRI and a macrophage-specific contrast agent. Am J Roentgenol Am J Roentgenol 2009; 193: W437-441

170 Heyn C, Ronald JA, Mackenzie LT et al. In vivo magnetic resonance imaging of single cells in mouse brain with optical validation. Magn Reson Med 2006; 55: 23-29

171 Kanno S, Wu YJ, Lee PC et al. Macrophage accumulation associated with rat cardiac allograft rejection detected by magnetic resonance imaging with ultrasmall superparamagnetic iron oxide particles. Circulation 2001; 104: 934-938

172 Zhang Y, Dodd SJ, Hendrich KS et al. Magnetic resonance imaging detection of rat renal transplant rejection by monitoring macrophage infiltration. Kidney Int 2000; 58: 1300-1310

173 Lutz AM, Seemayer C, Corot C et al. Detection of synovial macrophages in an experimental rabbit model of antigen-induced arthritis: ultrasmall superparamagnetic iron oxide-enhanced MR imaging. Radiology 2004; 233: 149-157

174 Kaim AH, Wischer T, O'Reilly T et al. MR imaging with ultrasmall superparamagnetic iron oxide particles in experimental soft-tissue infections in rats. Radiology 2002; 225: 808-814

175 Gellissen J, Axmann C, Prescher A et al. Extra- and intracellular accumulation of ultrasmall superparamagnetic iron oxides (USPIO) in experimentally induced abscesses of the peripheral soft tissues and their effects on magnetic resonance imaging. Magn Reson Imaging 1999; 17: 557-567

176 Luciani A, Dechoux S, Deveaux V et al. Adipose tissue macrophages: MR tracking to monitor obesity-associated inflammation. Radiology 2012; $263: 786-793$
177 Dousset V, Delalande C, Ballarino L et al. In vivo macrophage activity imaging in the central nervous system detected by magnetic resonance. Magn Reson Med 1999; 41: 329-333

178 Floris S, Blezer EL, Schreibelt G et al. Blood-brain barrier permeability and monocyte infiltration in experimental allergic encephalomyelitis: a quantitative MRI study. Brain 2004; 127: 616-627

179 Luchetti A, Milani D, Ruffini F et al. Monoclonal antibodies conjugated with superparamagnetic iron oxide particles allow magnetic resonance imaging detection of lymphocytes in the mouse brain. Mol Imaging 2012; 11: 114-125

180 Anderson SA, Shukaliak-Quandt J, Jordan EK et al. Magnetic resonance imaging of labeled T-cells in a mouse model of multiple sclerosis. Ann Neurol 2004; 55: 654-659

181 Rausch M, Sauter A, Frohlich J et al. Dynamic patterns of USPIO enhancement can be observed in macrophages after ischemic brain damage. Magn Reson Med 2001; 46: 1018-1022

182 Oude EngberinkRD, Blezer EL, Hoff EI et al. MRI of monocyte infiltration in an animal model of neuroinflammation using SPIO-labeled monocytes or free USPIO. J Cereb Blood Flow Metab 2008; 28: 841 -851

183 Zhu Y, Ling Y, Zhong J et al. Magnetic resonance imaging of radiationinduced brain injury using targeted microparticles of iron oxide. Acta Radiol 2012; 53: 812-819

184 Wadghiri YZ, Sigurdsson EM, Sadowski $M$ et al. Detection of Alzheimer's amyloid in transgenic mice using magnetic resonance microimaging. Magn Reson Med 2003; 50: 293-302

185 Yang J, Wadghiri YZ, Hoang DM et al. Detection of amyloid plaques targeted by USPIO-Abeta1-42 in Alzheimer's disease transgenic mice using magnetic resonance microimaging. Neuroimage 2011; 55: $1600-1609$

186 Weissleder R. Scaling down imaging: molecular mapping of cancer in mice. Nat Rev Cancer 2002; 2: 11 - 18

187 Schellenberger E. Bioresponsive nanosensors in medical imaging. J R Soc Interface 2010; 7: S83-S91

188 Koh I, Josephson L. Magnetic nanoparticle sensors. Sensors 2009; 9 : $8130-8145$

189 Perez JM, Josephson L, O'Loughlin T et al. Magnetic relaxation switches capable of sensing molecular interactions. Nat Biotechnol 2002; 20: $816-820$

190 Zhao M, Josephson L, Tang Y et al. Magnetic sensors for protease assays. Angew Chem Int Ed Engl 2003; 42: 1375-1378

191 Louie AY, Huber MM, Ahrens ET et al. In vivo visualization of gene expression using magnetic resonance imaging. Nat Biotechnol 2000; 18: $321-325$

192 Schellenberger E, Rudloff F, Warmuth $C$ et al. Protease-specific nanosensors for magnetic resonance imaging. Bioconjug Chem 2008; 19: $2440-2445$

193 Grimm J, Perez JM, Josephson L et al. Novel nanosensors for rapid analysis of telomerase activity. Cancer Res 2004; 64: 639-643

194 Perez JM, Grimm J, Josephson L et al. Integrated nanosensors to determine levels and functional activity of human telomerase. Neoplasia 2008; 10: 1066 - 1072

195 Hamm B, Staks T, Taupitz M et al. Contrast-enhanced MR imaging of liver and spleen: first experience in humans with a new superparamagnetic iron oxide. J Magn Reson Imaging 1994; 4: 659-668

196 Yoshikawa K, Sasaki Y, Ogawa N et al. Clinical application of AMI-25 (superparamagnetic iron oxide) for the MR imaging of hepatic tumors: a multicenter clinical phase III study. Nihon Igaku Hoshasen Gakkai Zasshi 1994; 54: 137-153

197 Ros PR, Freeny PC, Harms SE et al. Hepatic MR imaging with ferumoxides: a multicenter clinical trial of the safety and efficacy in the detection of focal hepatic lesions. Radiology 1995; 196: 481 - 488

198 Kopp AF, Laniado M, Dammann Fet al. MR imaging of the liver with Resovist: safety, efficacy, and pharmacodynamic properties. Radiology 1997; 204: 749-756

199 Bonnemain B. Pharmacokinetic and hemodynamic safety of two superparamagnetic agents, Endorem and Sinerem, in cirrhotic rats. Acad Radiol 1998; 5: S151 -S153 discussion S156

200 Kehagias DT, Gouliamos AD, Smyrniotis V et al. Diagnostic efficacy and safety of MRI of the liver with superparamagnetic iron oxide particles (SH U 555 A). J Magn Reson Imaging 2001; 14: 595-601

201 Onishi H, Murakami T, Kim T et al. Safety of ferucarbotran in MR imaging of the liver: a pre- and postexamination questionnaire-based multicenter investigation. J Magn Reson Imaging 2009; 29: 106-111 
202 Lee N, Hyeon T. Designed synthesis of uniformly sized iron oxide nanoparticles for efficient magnetic resonance imaging contrast agents. Chem Soc Rev 2012; 41: 2575-2589

203 Ito A, Kuga Y, Honda $\mathrm{H}$ et al. Magnetite nanoparticle-loaded antiHER2 immunoliposomes for combination of antibody therapy with hyperthermia. Cancer Lett 2004; 212: 167-175

204 Hadjipanayis CG, Machaidze R, Kaluzova $M$ et al. EGFRvIII antibodyconjugated iron oxide nanoparticles for magnetic resonance imaging-guided convection-enhanced delivery and targeted therapy of glioblastoma. Cancer Res 2010; 70: 6303-6312

205 Liao C, Sun Q, Liang B et al. Targeting EGFR-overexpressing tumor cells using Cetuximab-immunomicelles loaded with doxorubicin and superparamagnetic iron oxide. Eur J Radiol 2011; 80: 699-705

206 Shinkai M, Le B, Honda $H$ et al. Targeting hyperthermia for renal cell carcinoma using human MN antigen-specific magnetoliposomes. Jpn J Cancer Res 2001; 92: 1138-1145

207 Sonvico F, Mornet S, Vasseur S et al. Folate-conjugated iron oxide nanoparticles for solid tumor targeting as potential specific magnetic hyperthermia mediators: synthesis, physicochemical characterization, and in vitro experiments. Bioconjug Chem 2005; 16: 1181-1188

208 Liang S, Wang Y, Yu J et al. Surface modified superparamagnetic iron oxide nanoparticles: as a new carrier for bio-magnetically targeted therapy. J Mater Sci Mater Med 2007; 18: 2297-2302

209 Kohler N, Sun C, Wang J et al. Methotrexate-modified superparamagnetic nanoparticles and their intracellular uptake into human cancer cells. Langmuir 2005; 21: 8858-8864

210 Huang C, Tang Z, Zhou Y et al. Magnetic micelles as a potential platform for dual targeted drug delivery in cancer therapy. Int J Pharm 2012; 429: 113-122

211 El-Dakdouki MH, Zhu DC, El-Boubbou K et al. Development of multifunctional hyaluronan-coated nanoparticles for imaging and drug delivery to cancer cells. Biomacromolecules 2012; 13: 1144-1151

212 Ernsting MJ, Foltz WD, Undzys E et al. Tumor-targeted drug delivery using MR-contrasted docetaxel - carboxymethylcellulose nanoparticles. Biomaterials 2012; 33: 3931 - 3941

$213 \mathrm{Ai} \mathrm{H}$. Layer-by-layer capsules for magnetic resonance imaging and drug delivery. Adv Drug Deliv Rev 2011; 63: 772 - 788

214 Choi J, Kim HY, Ju EJ et al. Use of macrophages to deliver therapeutic and imaging contrast agents to tumors. Biomaterials 2012; 33: $4195-4203$

215 Kemmner W, Moldenhauer G, Schlag P et al. Separation of tumor cells from a suspension of dissociated human colorectal carcinoma tissue by means of monoclonal antibody-coated magnetic beads. J Immunol Methods 1992; 147: 197-200

216 Kronick P, Gilpin RW. Use of superparamagnetic particles for isolation of cells. J Biochem Biophys Methods 1986; 12: 73-80

217 Scherer F, Anton M, Schillinger U et al. Magnetofection: enhancing and targeting gene delivery by magnetic force in vitro and in vivo. Gene Ther 2002; 9: $102-109$

218 Chanana M, Mao Z, Wang $D$. Using polymers to make up magnetic nanoparticles for biomedicine. J Biomed Nanotechnol 2009; 5: 652 - 668

219 Akbarzadeh A, Samiei M, Davaran S. Magnetic nanoparticles: preparation, physical properties, and applications in biomedicine. Nanoscale Res Lett 2012; 7: 144

220 Frimpong RA, Hilt JZ. Magnetic nanoparticles in biomedicine: synthesis, functionalization and applications. Nanomedicine 2010; 5: $1401-1414$

221 Plank C, Scherer F, Schillinger U et al. Magnetofection: enhancing and targeting gene delivery with superparamagnetic nanoparticles and magnetic fields. J Liposome Res 2003; 13: 29-32

222 Krotz F, de Wit C, Sohn HY et al. Magnetofection - a highly efficient tool for antisense oligonucleotide delivery in vitro and in vivo. Mol Ther 2003; 7: 700-710

223 Shao $H$, Yoon TJ, Liong $M$ et al. Magnetic nanoparticles for biomedical NMR-based diagnostics. Beilstein J Nanotechnol 2010; 1: 142 - 154

224 Koh I, Hong R, Weissleder $R$ et al. Sensitive NMR sensors detect antibodies to influenza. Angew Chem Int Ed Engl 2008; 47: 4119-4121

225 Lee H, Yoon TJ, Weissleder R. Ultrasensitive detection of bacteria using core-shell nanoparticles and an NMR-filter system. Angew Chem Int Ed Engl 2009; 48: 5657-5660

226 Haun JB, Castro CM, Wang $R$ et al. Micro-NMR for rapid molecular analysis of human tumor samples. Sci Transl Med 2011; 3: 71ra16

227 Lee H, Sun E, Ham D et al. Chip-NMR biosensor for detection and molecular analysis of cells. Nat Med 2008; 14: 869-874

228 Borgert J, Schmidt JD, Schmale I et al. Fundamentals and applications of magnetic particle imaging. J Cardiovasc Comput Tomogr 2012; 6: $149-153$

229 Weizenecker J, Gleich B, Rahmer J et al. Three-dimensional real-time in vivo magnetic particle imaging. Phys Med Biol 2009; 54: L1 - L10

230 Weizenecker J, Borgert J, Gleich B. A simulation study on the resolution and sensitivity of magnetic particle imaging. Phys Med Biol 2007; 52: $6363-6374$

231 Haegele J, Sattel T, Erbe $M$ et al. Magnetic particle imaging (MPI) Fortschr Röntgenstr 2012; 184: 420-426 